Chicago Riverwalk, Phases 2 \& 3

Methods

Research Fellow:

Sarah Hanson

Adjunct Professor

Illinois Institute of Technology

Research Assistant:

Matt Callone

MLA Candidate

Illinois Institute of Technology

Firm Liaison:

Steve Walz

Associate

Sasaki Associates

This investigation was conducted as part of the Landscape Architecture Foundation's 2019 Case Study Investigation (CSI) program. CSI matches faculty-student research teams with design practitioners to document the benefits of exemplary high-performing landscape projects. Teams develop methods to quantify environmental, social, and economic benefits and produce Case Study Briefs for LAF's Landscape Performance Series.

To cite:

Hanson, Sarah, and Matthew Callone. "Chicago Riverwalk, Phases 2 \& 3 Methods." Landscape Performance Series. Landscape Architecture Foundation, 2019. https://doi.org/10.31353/cs1501

The full case study can be found at: https://landscapeperformance.org/case-studybriefs/chicago-riverwalk 


\section{Environmental Benefits}

- Increases ecological quality as demonstrated by an increase in Floristic Quality Index (FQI) from 0 to 38.2 in an area of 19,529 sf. An FQI above 35 is considered to be "natural area" quality.

Methods: Area takeoff calculations of each "room" as represented by the Chicago Riverwalk Phase 2 and 3 bid drawings were taken and totaled using AutoCAD 2017 to determine the amount of habitat area (sf) created on the project site (Table 2).

The Universal Floristic Quality Assessment (FQA) calculator was used to evaluate the ecological integrity of the native plant communities on site. Plant schedules of species were provided per the construction documents for both before and after construction. The FQA calculator provided the coefficient of conservatism (C) for each species listed. The total Floristic Quality Index (FQI) was determined by multiplying the mean $\mathrm{C}$ by the square root of the total amount of species $(\mathrm{N})$ on each list (Table 3 ). There was previously no vegetation along the riverwalk path, so the previous FQI value may be assumed to be 0 .

\section{Calculations:}

\begin{tabular}{|l|r|}
\hline & $\begin{array}{l}\text { Habitat Area } \\
\text { (sf) }\end{array}$ \\
\hline Marina & 3,542 \\
\hline Cove & 2,386 \\
\hline River Theater & 8,048 \\
\hline Water Plaza & 1,821 \\
\hline The Jetty & 3,732 \\
\hline TOTAL & $\mathbf{1 9 , 5 2 9}$ \\
\hline
\end{tabular}

Table 2: Habitat Area Calcs

Source: Sasaki Construction Drawings

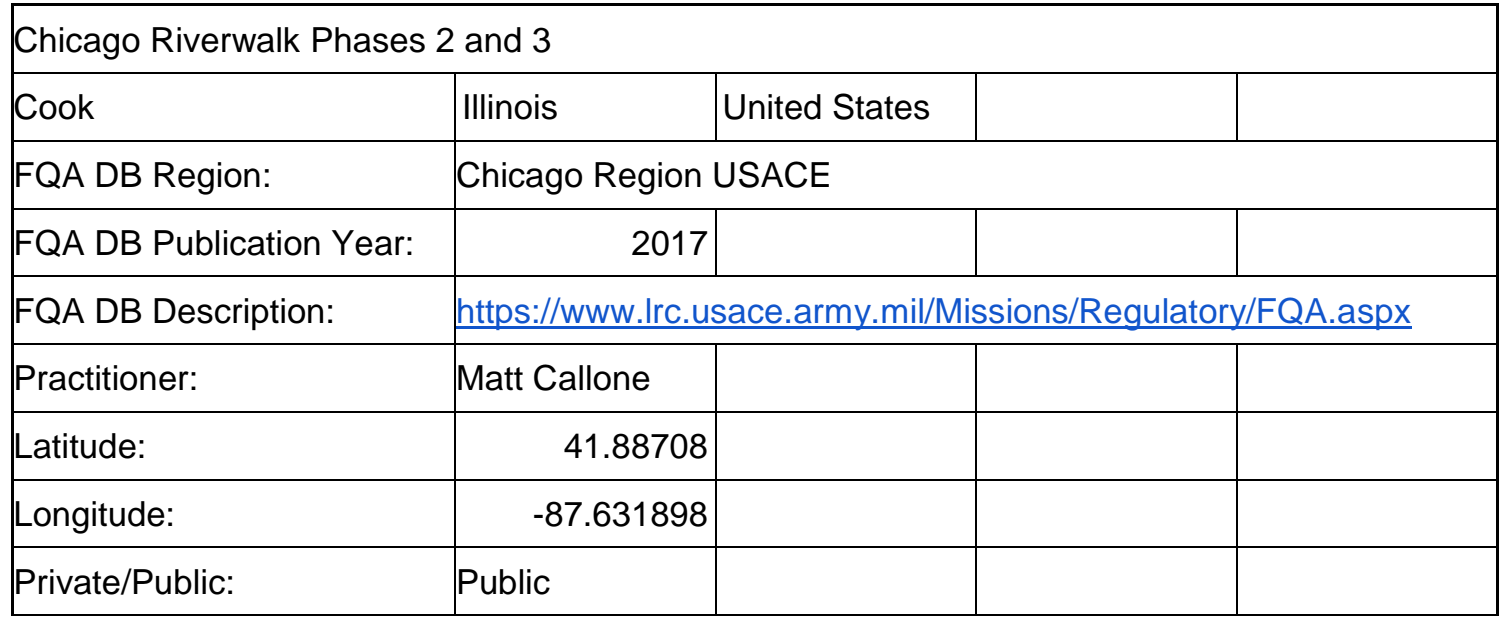




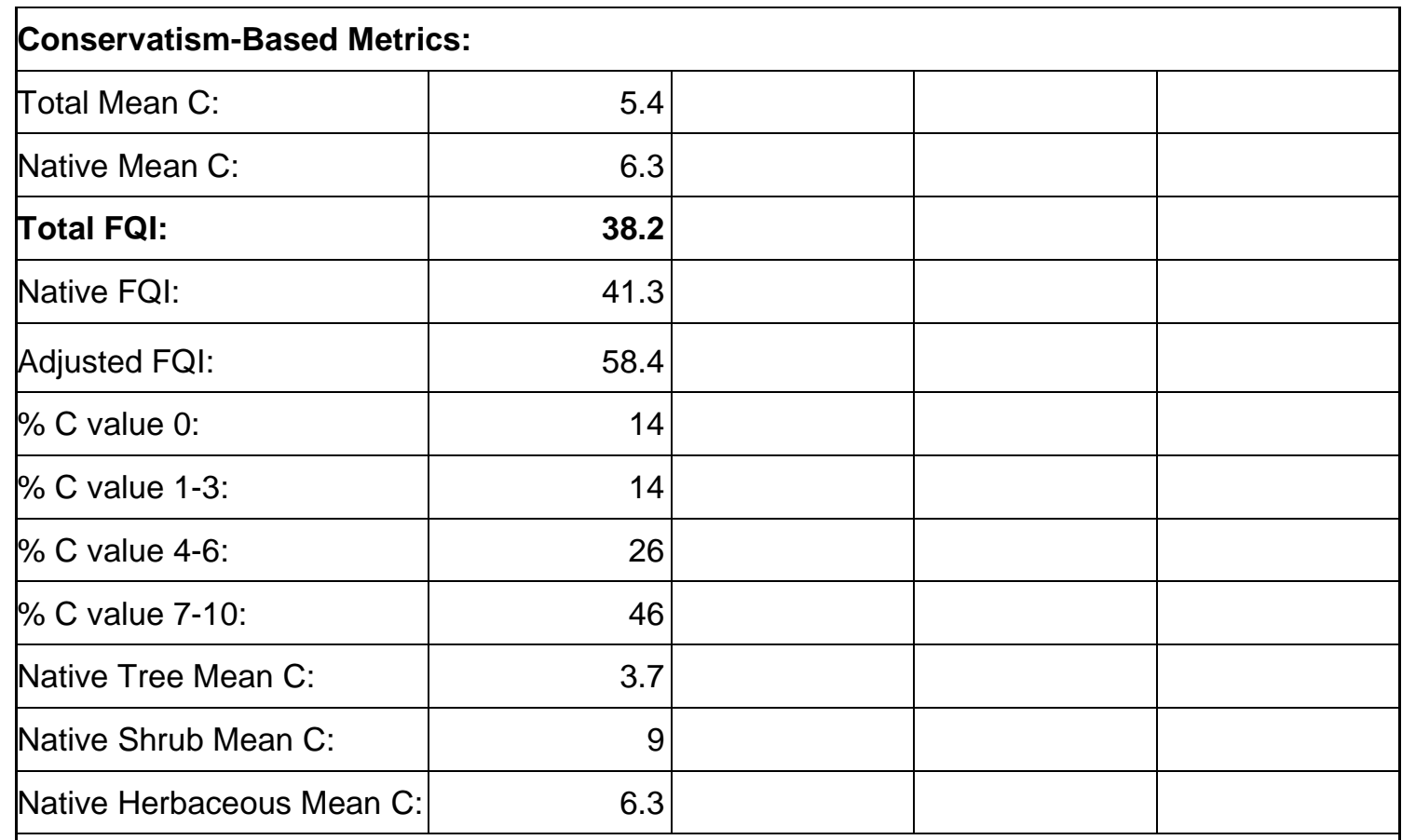

\section{Species Richness:}

\begin{tabular}{|l|r|r|l|l|}
\hline Total Species: & 50 & & & \\
\hline Native Species: & 43 & $86 \%$ & & \\
\hline Non-native Species: & 7 & $14 \%$ & & \\
\hline
\end{tabular}

Table 3: Chicago Riverwalk FQA Report* Source: Universal FQA Calculator

${ }^{*}$ Complete report found in Appendix A

\section{Sources:}

“Chicago Riverwalk Phases 2 and 3." Universal FQA Calculator. July 28, 2019. https://universalfqa.org/view_inventory/15067.

Freyman, W.A., L.A. Masters, and S. Packard. 2016. The Universal Floristic Quality Assessment

(FQA) Calculator: an online tool for ecological assessment and monitoring. Methods in Ecology and Evolution. 7(3): 380-383

Sasaki Associates, Inc., Ross Barney Architects, Alfred Benesch and Co., Infrastructure Engineering, Rubino and Mesia, Delta Engineering, Jacobs/Ryan Associates, Schuler Shook, Dynasty Group, and Geo Services. Chicago Riverwalk State Street to LaSalle Street Bid Drawings. PDF. Chicago: City of Chicago Dept. of Transportation Div. of Engineering, July 22, 2013.

Sasaki Associates, Inc., Ross Barney Architects, Alfred Benesch and Co., Infrastructure Engineering, Rubino and Mesia, Delta Engineering, Jacobs/Ryan Associates, Schuler Shook, Architect Consulting Inc., Fluidity Design Consultants. Dynasty Group, and Geo Services. Chicago Riverwalk LaSalle Street to Lake Street Bid Drawings. PDF. Chicago: 
City of Chicago Dept. of Transportation Div. of Engineering, October 30, 2014.

Limitations:

The planting schedules were not verified in the field by the research team, and plants actually present on site may vary from construction documents. A vegetation survey was not possible within the time frame of this evaluation.

\section{Social Benefits}

- Attracts approximately 780 visitors on a typical summer weekend afternoon. $73 \%$ of observed visitors engaged in commerce-related activities, $20 \%$ in leisure activities, and $8 \%$ in recreational activities. $34 \%$ of 353 surveyed visitors selfreport that they visit the Riverwalk 1-3 times per month.

Methods: On August 26, 2017, a University of Michigan (UM) research team counted the number of visitors to the Chicago Riverwalk from 9am to $5 \mathrm{pm}$. The observations were conducted for the first five minutes of every 30 minutes (Figure 3). At the peak time of 3pm, 780 visitors were observed staying at the Riverwalk. The UM team defined "stay" as people who have already been in a room at the beginning of every 30 minutes.

On July 28, 2019, the LAF Research Team counted visitors to the Chicago Riverwalk and the Chicago River along the Riverwalk by type of activity engaged in from $1 \mathrm{pm}$ to $2 \mathrm{pm}$ on a sunny afternoon in ten-minute intervals in each "room" of the Riverwalk. The Gehl Institute protocols helped to guide how activities would be categorized (Table 5). The Gehl Institute categories selected for observation were recreation play/exercise, commercial, and cultural. Leisure activities were defined by the research team as unaffiliated activities involving stationary relaxation (i.e. sitting, lounging, laying down). A total of 1,120 visitors were observed engaged in either recreational, commercial, or leisure activities, and these results were tallied by category and taken as a percentage (Table 6). Cultural activities were not observed.

From August 17-21, 2017, the UM research team distributed surveys in each of the 6 "rooms" in the project scope, and received 354 surveys back. 92/270, or $34 \%$, of those surveyed responded "1-3 times per month" to the question, "How often do you visit the Chicago Riverwalk?" (Figure 4).

\begin{tabular}{|c|c|}
\hline \multirow{2}{*}{$\begin{array}{l}\text { Recreation } \\
\text { Play/Exercise* } \\
\text { *types of visitor } \\
\text { observed on July 28, }\end{array}$} & $\begin{array}{l}\text { Exercising in designated (formal) sports areas, using designated (formal) public sporting equipment, like } \\
\text { fixed basketball net. }\end{array}$ \\
\hline & $\begin{array}{l}\text { Exercising outside of designated (informal) sports areas, using privately-owned equipment, like a jump rope, } \\
\text { or no equipment at all. }\end{array}$ \\
\hline
\end{tabular}




\begin{tabular}{|c|c|}
\hline \multirow{2}{*}{$\begin{array}{l}\text { 2019: runner, } \\
\text { bicyclist, kayaker, } \\
\text { child in fountain }\end{array}$} & Playing in a designated (formal) play area, or with designated (formal) public play equipment. \\
\hline & $\begin{array}{l}\text { Playing outside of a designated (informal) play area, or playing with privately-owned play equipment. Also a } \\
\text { person playing with a dog. }\end{array}$ \\
\hline \multirow{6}{*}{$\begin{array}{l}\text { Commercial }^{*} \\
\text { *types of visitors } \\
\text { observed on July 28, } \\
\text { 2019: restaurant } \\
\text { customer/server, bar } \\
\text { customer/server, tour } \\
\text { boat customer/staff }\end{array}$} & Selling food or goods in an established/legal (formal) setting or in a self-constructed/illegal (informal) setting. \\
\hline & $\begin{array}{l}\text { Person doing backend activities related to commercial activities, like a waiter bussing tables, a person } \\
\text { loading commercial goods, or a person setting up a commercial stall. }\end{array}$ \\
\hline & $\begin{array}{l}\text { the process of buying foods and goods. Both the person performing a transaction, and the people queuing } \\
\text { are counted as buyers. }\end{array}$ \\
\hline & $\begin{array}{l}\text { A person who is participating in a commercial situation, without being either a provider or a buyer/shopper in } \\
\text { the moment of the survey, is }\end{array}$ \\
\hline & $\begin{array}{l}\text { counted as participating by being an observer. This could be a person browsing the produce at a market } \\
\text { stall, but who has not yet committed }\end{array}$ \\
\hline & naking a purchase, either by an exchange of money or by queuing up to making a transaction of money. \\
\hline
\end{tabular}

Table 5: Category descriptions for activities from the Public Life Date Protocol. Source: Gehl Institute

\section{Calculations:}

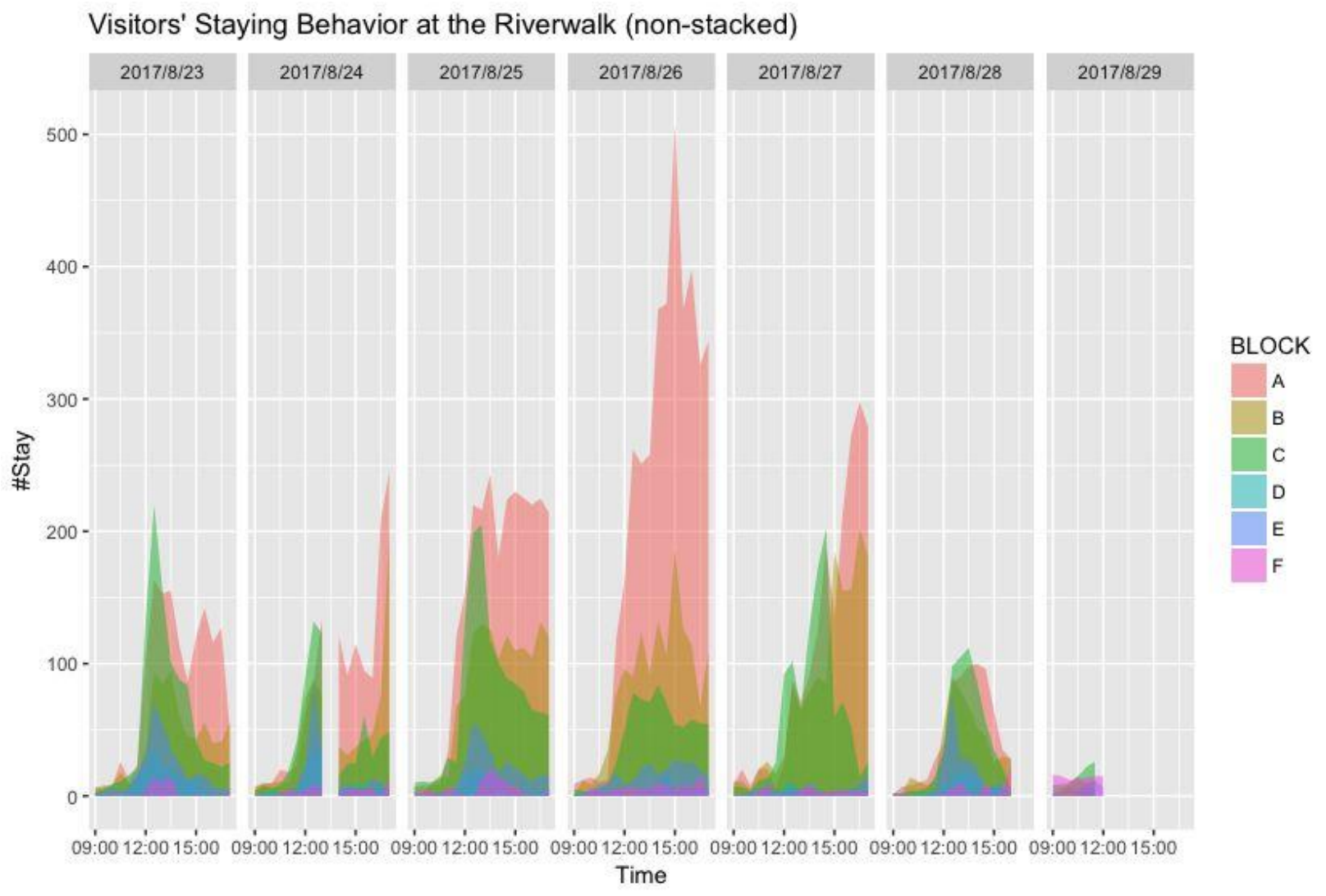

Figure 3: Visitors staying behavior at the Riverwalk. Source: University of Michigan 


\begin{tabular}{|l|r|r|r|r|r|}
\hline & Recreation & Commercial & Cultural & Leisure \\
\hline Marina Plaza & 24 & 307 & 0 & 84 \\
\hline Cove & 9 & 348 & 0 & 29 \\
\hline River Theater & 9 & 137 & 0 & 65 \\
\hline Jetty & 32 & 0 & 0 & 20 \\
\hline Confluence & 13 & 20 & 0 & 23 \\
\hline TOTAL & 87 & 812 & 0 & 221 \\
\hline Percent of TOTAL & $7.77 \%$ & $72.50 \%$ & $0.00 \%$ & $19.73 \%$ \\
\hline Table
\end{tabular}

Table 6: Pedestrian counts taken on July 28, 2019 by category. Source: LAF Research Team

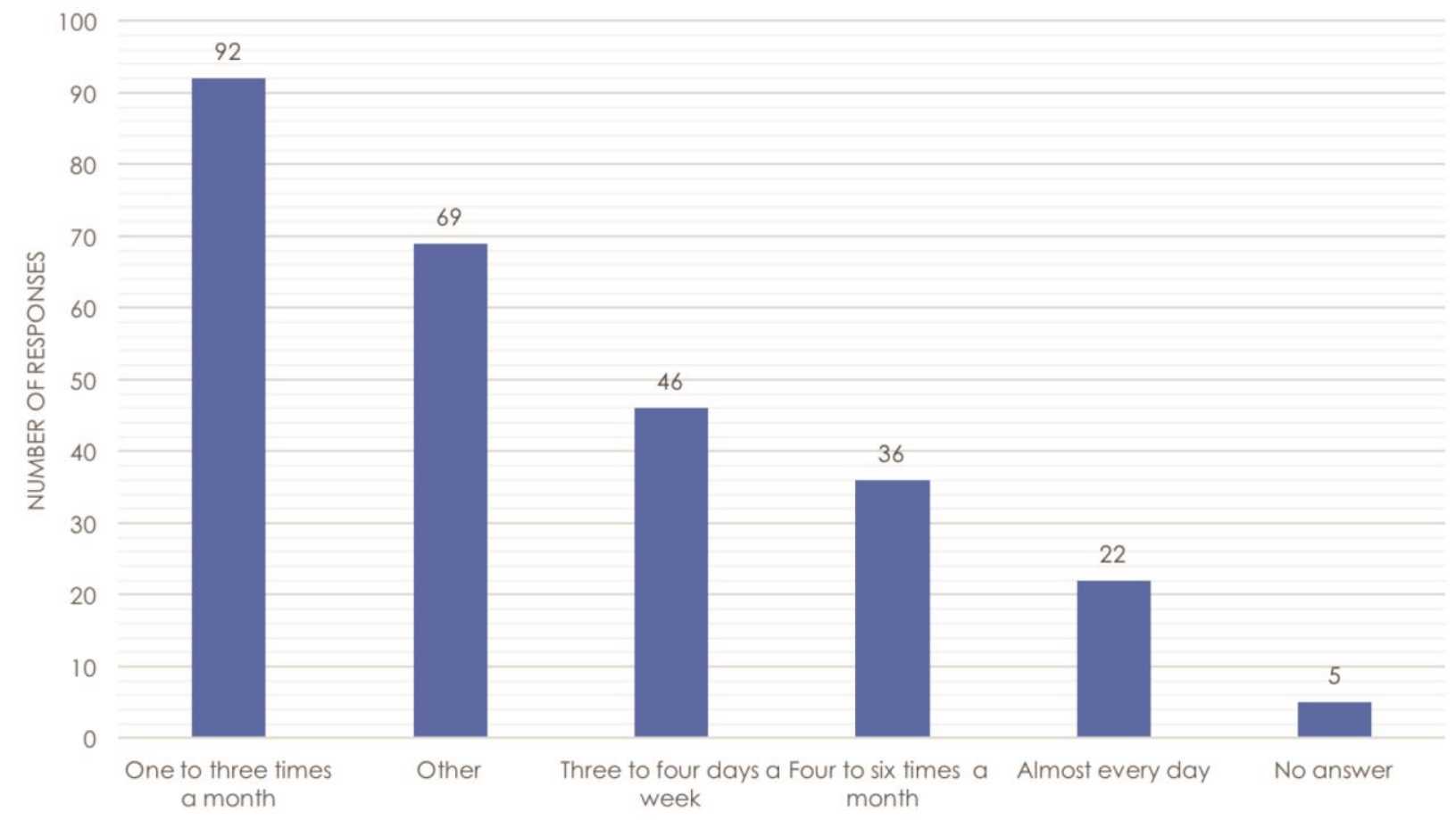

Figure 4: Frequency of visitation to the Chicago Riverwalk as self-reported by those surveyed in August of 2017. Source: University of Michigan

Sources:

Hsieh, Ho, Xuehan Li, Shui Wang, and Yifei Wu. "Post-Occupancy Evaluation of the Chicago Riverwalk." Master's thesis, University of Michigan, 2018. April 2018. Accessed May 29, 2018. http://hdl.handle.net/2027.42/143161.

The Open Public Life Data Protocol Version: Beta. PDF. New York: Gehl Institute, City of San Francisco's Planning Department, Copenhagen Municipality's City Data Department, Seattle Department of Transportation, Gehl, September 27, 2017.

https://gehlinstitute.org/tool/public-life-data-protocol/ 
Limitations: The "leisure" category was defined by the research team selected because of assumptions made that the stationary activity mapping's predefined categories for postures were leisure positions. University of Michigan data was not independently verified by the LAF Research Team.

- Provides a venue for Chicago Park District public programming and large-scale events, including the Art on the MART launch (2018) with 32,000 attendees, the Floating Museum exhibit (2017) with over 90,000 attendees, and environmental programs (2018) for over 1,100 children.

The expansion of the Chicago Riverwalk has facilitated an increase in programming and visitors to the promenade. Through partnerships, the Department of Fleet and Facility Management (2FM) continuously finds opportunities for Riverwalk programming, including opening day celebrations, free guided tours, and vendor and entertainment events in the Confluence room. 2FM continuously asks for performance evaluations of the Riverwalk programming and responds accordingly. For example, in response to vendor reports as Tuesdays being the lowest attendance day on the Riverwalk, 2FM launched Second Tuesday to draw more visitors to the Riverwalk.

Methods: 2FM provided an 8-year report of Riverwalk programming entitled "Chicago Riverwalk: 8 Years (2011-2018) Of Creating and Rebuilding", listing programming highlights for 2017 and 2018. A full list of programming highlights is found in Table 7.

Calculations:

\begin{tabular}{|l|l|}
\hline 2017 Programming Highlights & \\
\hline Opening Day Celebration & 25 activities \\
\hline Public Art on the Riverwalk & 5 works of public art \\
\hline $\begin{array}{l}\text { 2nd Tuesdays Music Cruise and } \\
\text { Pyrotechnics }\end{array}$ & 5 Chicago bands \\
\hline $\begin{array}{l}\text { Monthly Fish Parades along the } \\
\text { Riverwalk }\end{array}$ & 20 fish-inspired puppets \\
\hline Floating Museum & 50 artists, 12 organizations, 23 programs, 90,000 viewers \\
\hline Unifest & 28 sister cities over 6 weeks \\
\hline Friday Night Flights & 14 breweries, 2 local entertainers, 4 Riverwalk vendors, 700 \\
\hline Riverwalk Oktoberfest & 22 local breweries, entertainment, specials along Riverwalk \\
\hline 2018 Programming Highlights & \\
\hline Opening Day Celebration & 20 activities \\
\hline $\begin{array}{l}\text { Chicago Loop Alliance ACTIVATE } \\
\text { event }\end{array}$ & bazaar \\
\hline
\end{tabular}




\begin{tabular}{|l|l|}
\hline $\begin{array}{l}\text { Chicago Dance Month Closing } \\
\text { Celebration and Scavenger Hunt }\end{array}$ & month-long celebration of dance, reception at City Winery \\
\hline Park District Programming & $\begin{array}{l}8,000 \text { invidual fish from } 11 \text { individual species caught, 1,100 kids, } 37 \\
\text { parks }\end{array}$ \\
\hline $\begin{array}{l}\text { Chicago Architecture Foundation } \\
\text { Docent Talks }\end{array}$ & every Friday, 45-minute talks \\
\hline Chicago Instagreeter Walks & $\begin{array}{l}\text { one-hour guided walks highlighting history, architecture and venues } \\
\text { of the Riverwalk }\end{array}$ \\
\hline Arts in the Dark Lantern & $\begin{array}{l}\text { Second Tuesday pageants, cultural organizations and participants } \\
\text { from After School Matters }\end{array}$ \\
\hline Processions & 15 breweries, local entertainers, specials along Riverwalk \\
\hline Activate the Confluence events & $\begin{array}{l}\text { five events, Riverwalk vendors, local entertainment, Chicago City } \\
\text { Market vendors }\end{array}$ \\
\hline Art of the MART launch event & 32,000 people \\
\hline
\end{tabular}

Table 7: 2017 and 2018 Chicago Riverwalk Programming Highlights. Source: City of Chicago

Sources:

Chicago Riverwalk: 8 Years (2011-2019) Of Creating and Rebuilding. Chicago, IL: City of Chicago, 2018

Limitations: Information was not available for the total amount of visitors or events on site since opening, so data was gathered from the list of 2017 and 2018 program highlights and art installations in the Chicago Riverwalk: 8 Years (2011-2019) Of Creating and Rebuilding brochure.

- Increases the level of satisfaction with the riverfront as according to $89 \%$ of 28 surveyed visitors who were familiar with the site before reconstruction.

- Provides a better understanding of the river's water level and aquatic life according to $26 \%$ of 47 surveyed visitors.

- Strengthens intermodal connections, with $42 \%$ of 50 surveyed visitors reporting using the Riverwalk as part of their commute. Of these, $24 \%$ travel by bicycle, scooter, or hoverboard and $62 \%$ travel on foot.

Methods and Calculations: On sunny afternoons on Thursday, July 4 from $1 \mathrm{pm}-3 \mathrm{pm}$ and Monday, July 8, 2019 from 4pm-6pm, the LAF research team distributed 50 surveys to visitors. The full survey can be found in Appendix B.

The survey asked visitors how satisfied they were with the Riverwalk improvements. Responses were recorded and tallied. 25/28 (28 were familiar with the site pre-construction), or 89\%, responded "more satisfied" (Table 8 ). 


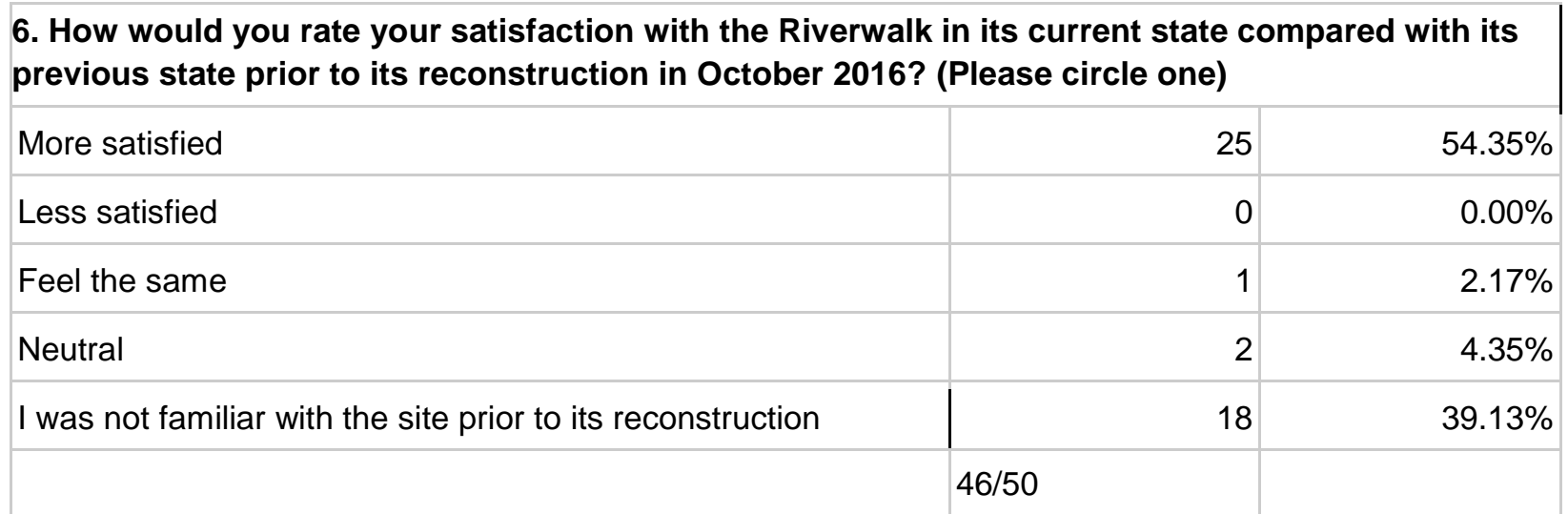

Table 8: User satisfaction as self-reported by surveyees on July 4 and 8, 2019 survey. Source: LAF Research Team

The survey asked visitors if they had a greater understanding of the water level and aquatic life of the river, and if so, which elements provided a better understanding of the river's hydrology and water life. Responses were tallied and taken as a percentage. 12/47, or $26 \%$, reported a better understanding (Table 9 ). $48 / 50$, or $96 \%$, selected elements of the Riverwalk as providing a greater understanding (Table 10).

The Chicago Riverwalk and associated programming provides various physical features and educational opportunities aimed at educating the public of the site's various environmental features, such as the floating wetlands and flood resilient pedestrian walk. Though $26 \%$ of those surveyed self-reported a better understanding of some of these features, $96 \%$ of those surveyed viewed site features, observation, recreation, or tours as giving them a greater understanding of the river's hydrology and water life. Public programming also promotes environmental awareness, including the 2017 monthly "Fish Parades" and 2018 children's environmental programs where children fished and discovered over 8,000 individual fish from 11 different species. For the programming data, the Department of Fleet and Facility Management (2FM) provided an 8-year report of Riverwalk programming entitled Chicago Riverwalk: 8 Years (20112018) Of Creating and Rebuilding, listing programming highlights for 2017 and 2018 (Table 7).

\section{By visiting the Chicago Riverwalk today, do you have a better understanding of the river's water level and aquatic life, such as fish, within the river? (Please circle one)}

\begin{tabular}{|l|r|r|}
\hline I better understand the river's water level and aquatic life. & 12 & $25.53 \%$ \\
\hline I do not better understand the river's water level and aquatic life. & 19 & $40.43 \%$ \\
\hline & & 16 \\
\hline I have the same understanding of the river's water level and aquatic life. & $34.04 \%$ \\
\hline
\end{tabular}

Table 9: User understanding of river hydrology and aquatic life as determined by July 4 and 8, 2019 survey. Source: LAF Research Team 
11. If you have a better understanding, which elements of the Chicago Riverwalk give you a greater understanding of the river's hydrology and aquatic life? (Please select all that apply)

\begin{tabular}{|l|r|r|}
\hline Floating wetlands & 8 & $16 \%$ \\
\hline Posts with water levels etched onto the surface & 7 & $14 \%$ \\
\hline Observation along the Riverwalk & 20 & $40 \%$ \\
\hline Physical recreation in the river such as kayaking, boating & 10 & $20 \%$ \\
\hline $\begin{array}{l}\text { Educational tour } \\
\text { Other, please } \\
\text { list: }\end{array}$ & 3 & $6 \%$ \\
\hline
\end{tabular}

Table 10: Elements that provide a greater understanding of the river's hydrology and aquatic life as determined by July 4 and 8, 2019 survey. Source: LAF Research Team

The Riverwalk promenade strengthens intermodal connections and better links trips by car, boat, bike, water taxi, public transit, and on foot. This includes a water taxi stop at the River Theater room. The survey asked visitors if they currently use the Riverwalk as part of their regular commute and their modes of transportation. $21 / 50$, or $42 \%$, selected at least one mode of transportation. Responses were recorded and tallied (Table 11).

13. If you currently use the Riverwalk as part of your commute, what is/are your mode(s) of transportation to arrive at your final destination? (Please select all that apply)

\begin{tabular}{|l|r|r|}
\hline Walking & 13 & $61.90 \%$ \\
\hline Biking & 3 & $14.29 \%$ \\
\hline Scooter/skateboard/hoverboard & 2 & $9.52 \%$ \\
\hline Train to Riverwalk & 3 & $14.29 \%$ \\
\hline Bus to Riverwalk & & $0.00 \%$ \\
\hline Water taxi & 1 & $0.00 \%$ \\
\hline Other & $4.76 \%$ \\
\hline The Riverwalk is not part of my regular commute & 29 & $58 \%$ \\
\hline
\end{tabular}

Table 11: Self-reported transportation modes as part of work commute as determined by July 4 and 8 , 2019 survey. Source: LAF Research Team

Sources:

Callone, Matt. Chicago Riverwalk User Survey. July 8, 2019. Raw data. Chicago Riverwalk, Chicago. 
Chicago Riverwalk: 8 Years (2011-2019) Of Creating and Rebuilding. Chicago, IL: City of Chicago, 2018

Limitations:

Survey data represents only one point in time. The research team is aware of the biases that occur with intercept surveys. The survey was limited to those surveyed at rush-hour times. For educational benefit: users surveyed by the LAF Research Team may have been confused by the two consecutive questions, as well as wording, concerning a better understanding of the river and habitat, and elements that provide a greater understanding, explaining the disparity between a minority of users questioned having a better understanding versus a majority associating elements of the Riverwalk that provide a greater understanding.

- Increased scenic quality of the Chicago Riverwalk, with scenic value index scores of views from the bridges increasing by 22 to 74 points. Additionally, $74 \%$ of 34 surveyed visitors reported an improved perception of the aesthetic quality of the riverfront.

Improvements to the scenic quality of the riverfront include closer views of the river by bringing the elevation of the riverwalk down by 5 feet in some locations, redeveloping former industrial and commercial sites, and extending the promenade with material and plant choices.

Methods: Before and after pictures of each Riverwalk "room" taken from the bridges above the site sized 10x8 inches were each cross-referenced to measure the area of scenic view based on a set of criteria, categories including vegetation, circulation and proximity to the river. The LAF research team referenced the Bureau of Land Management's Visual Resource Inventory's evaluation of scenic quality categories of: "vegetation," "water," "cultural modifications," and "color" and selected vegetation, circulation (a cultural modification and color choice) and proximity to the river as categories for scenic quality evaluation. The scenic quality was measured through a takeoff of the category areas for each photo in AutoCAD 2017. The positive area of vegetation and circulation (as expressed in square inches on a photograph) is considered a net increase in the area of scenic view. The negative area between the riverwalk and river, visually seen as a decrease in the distance between the ledge of the pedestrian walkway and the river, or, rather, a closer proximity to the water, is considered a net increase in the area of scenic quality of the Riverwalk. The total area of these three categories gives each before and after picture an equivalent scenic quality index (SQI) in units of square inches higher scores mean a higher scenic quality (Figure 5).

To supplement this analysis, surveyed visitors were asked if they their perceptions of aesthetic qualities had improved after the redesign to see if there was a positive correlation between survey results and the SQI results. On sunny afternoons on Thursday, July 4 from 1pm-3pm and Monday, July 8, 2019 from 4pm-6pm, the LAF research team distributed 50 surveys and asked visitors if they find the Chicago Riverwalk to have improved in aesthetic, environmental, cultural and/or accessibility quality. Responses were recorded and tallied. $26 / 35$, or $74 \%$, of 
surveyees who were familiar with the site before its reconstruction selected "aesthetic" as one of the ways they perceived improvement (Table 13). The full survey can be found in Appendix B.

Calculations:

\begin{tabular}{|c|c|c|c|c|c|c|c|c|c|}
\hline & \multicolumn{4}{|c|}{ Before (si) } & \multicolumn{4}{|c|}{ After (si) } & \multirow[b]{2}{*}{$\begin{array}{c}\text { SQI Net } \\
\text { Gain }\end{array}$} \\
\hline & $\begin{array}{c}\text { Vegetati } \\
\text { on }\end{array}$ & $\begin{array}{c}\text { Circulati } \\
\text { on }\end{array}$ & $\begin{array}{l}\text { Proximity } \\
\text { to River }\end{array}$ & SQI & $\begin{array}{c}\text { Vegetat } \\
\text { ion }\end{array}$ & $\begin{array}{c}\text { Circulati } \\
\text { on }\end{array}$ & $\begin{array}{c}\text { Proximity to } \\
\text { River }\end{array}$ & SQI & \\
\hline Marina & 1.85 & 6.52 & -7.96 & 0.41 & 19.89 & 29.4 & -0.48 & 48.81 & 48.4 \\
\hline Cove & 1.31 & 6.61 & -6 & 1.92 & 8.44 & 19.88 & -0.5 & 27.82 & 25.9 \\
\hline $\begin{array}{l}\text { River } \\
\text { Theater }\end{array}$ & 1.11 & 6.26 & -10.53 & -3.16 & 41.07 & 30.45 & -0.66 & 70.86 & 74.02 \\
\hline $\begin{array}{l}\text { Water } \\
\text { Plaza }\end{array}$ & 1.39 & 14.3 & -4.3 & 11.39 & 25.13 & 18.06 & 0 & 43.19 & 31.8 \\
\hline Jetty & 1.2 & 12.73 & -8.39 & 5.54 & 14.7 & 19.37 & -6.005 & 28.06 & 22.525 \\
\hline Confluence & 0.65 & 0 & 2.89 & 3.54 & 4.48 & 25.96 & -0.3717 & 30.06 & 26.5283 \\
\hline Total SQI & & & & 19.64 & & & & $\begin{array}{r}248.813 \\
3\end{array}$ & 229.1733 \\
\hline
\end{tabular}

Table 12: Scenic Quality Calculations. Units are in square inches. Source: LAF Research Team

As shown in this table, a net gain of scenic quality is achieved in the project from these specific vantage points of the bridges over the Chicago River toward each "room". A total area of $229 \mathrm{in}^{2}$ is visible in the study area after the project was installed. The increased visible gain area is $1166 \%$. Light green signifies vegetation, bright green signifies circulation and dark green signifies proximity to the river.

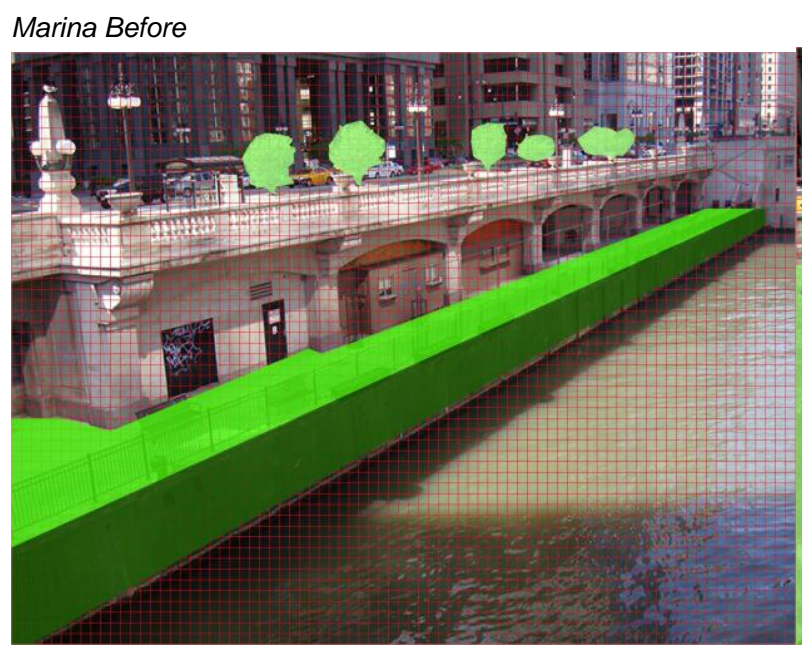

Cove Before
Marina After

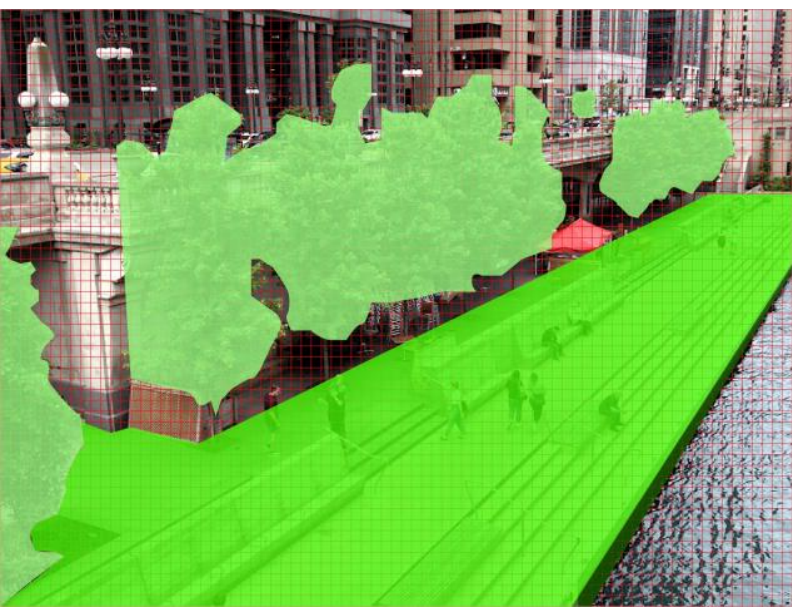

Cove After 


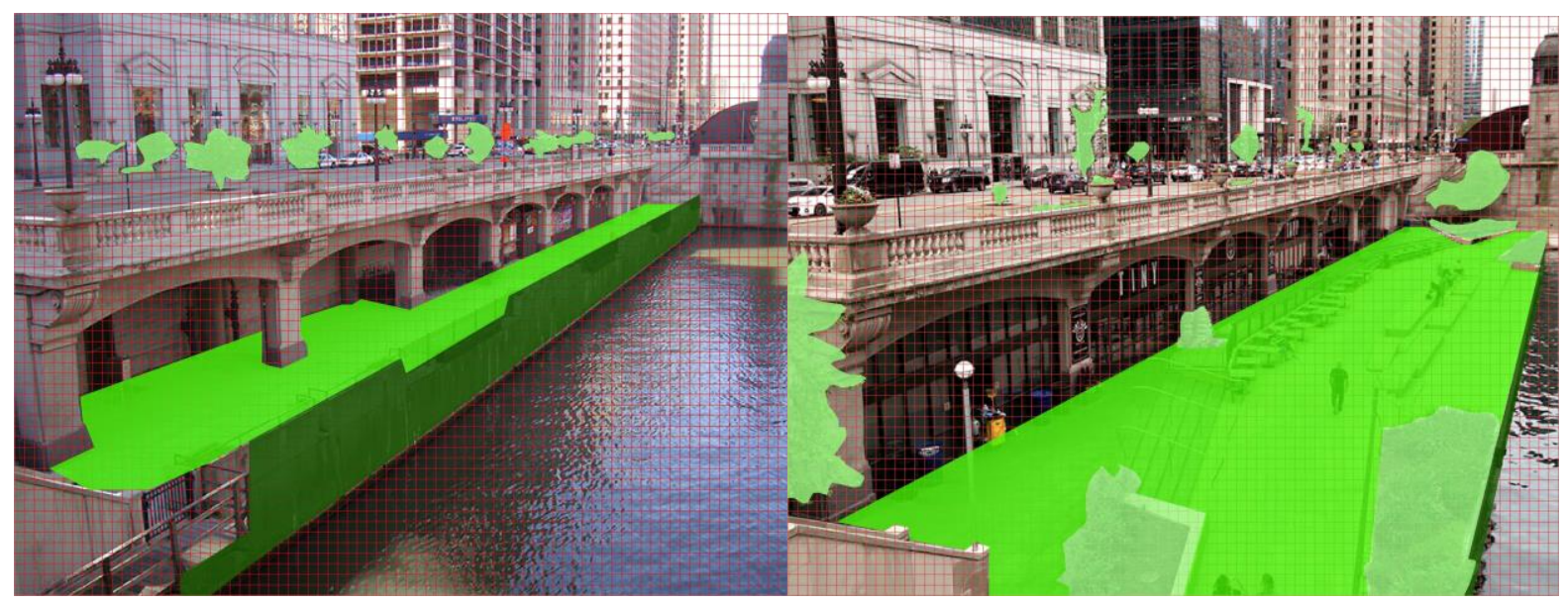

River Theater Before

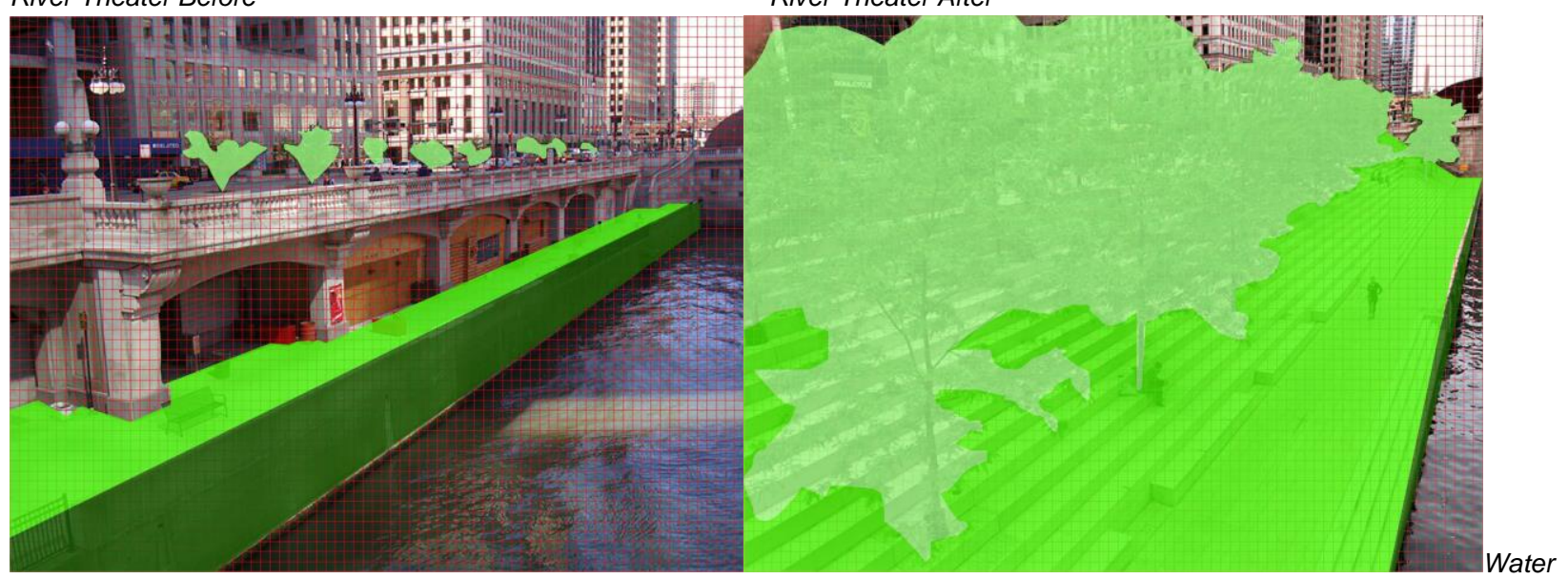

Plaza Before

Water Plaza After

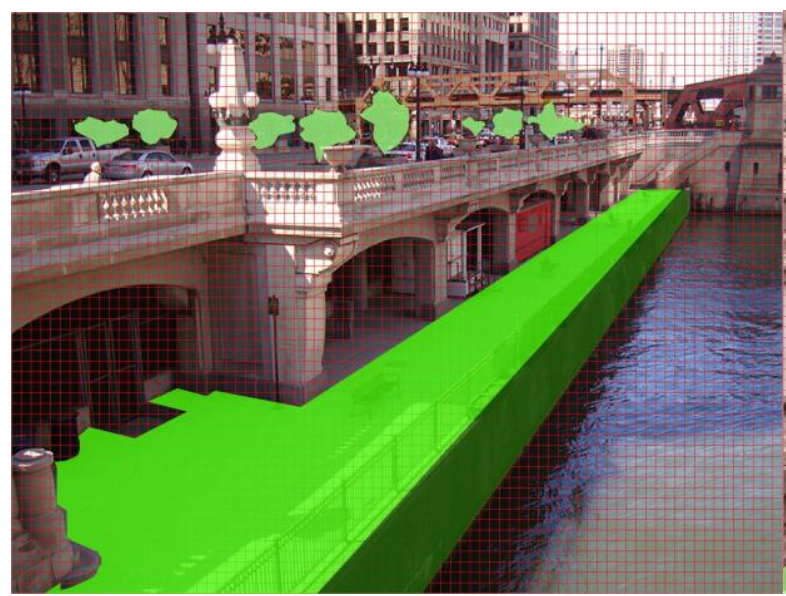

Jetty Before

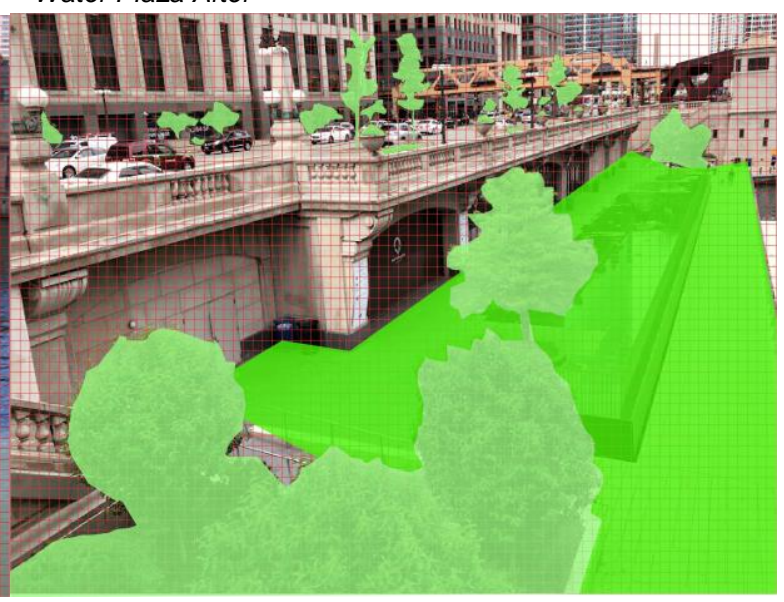

Jetty After 

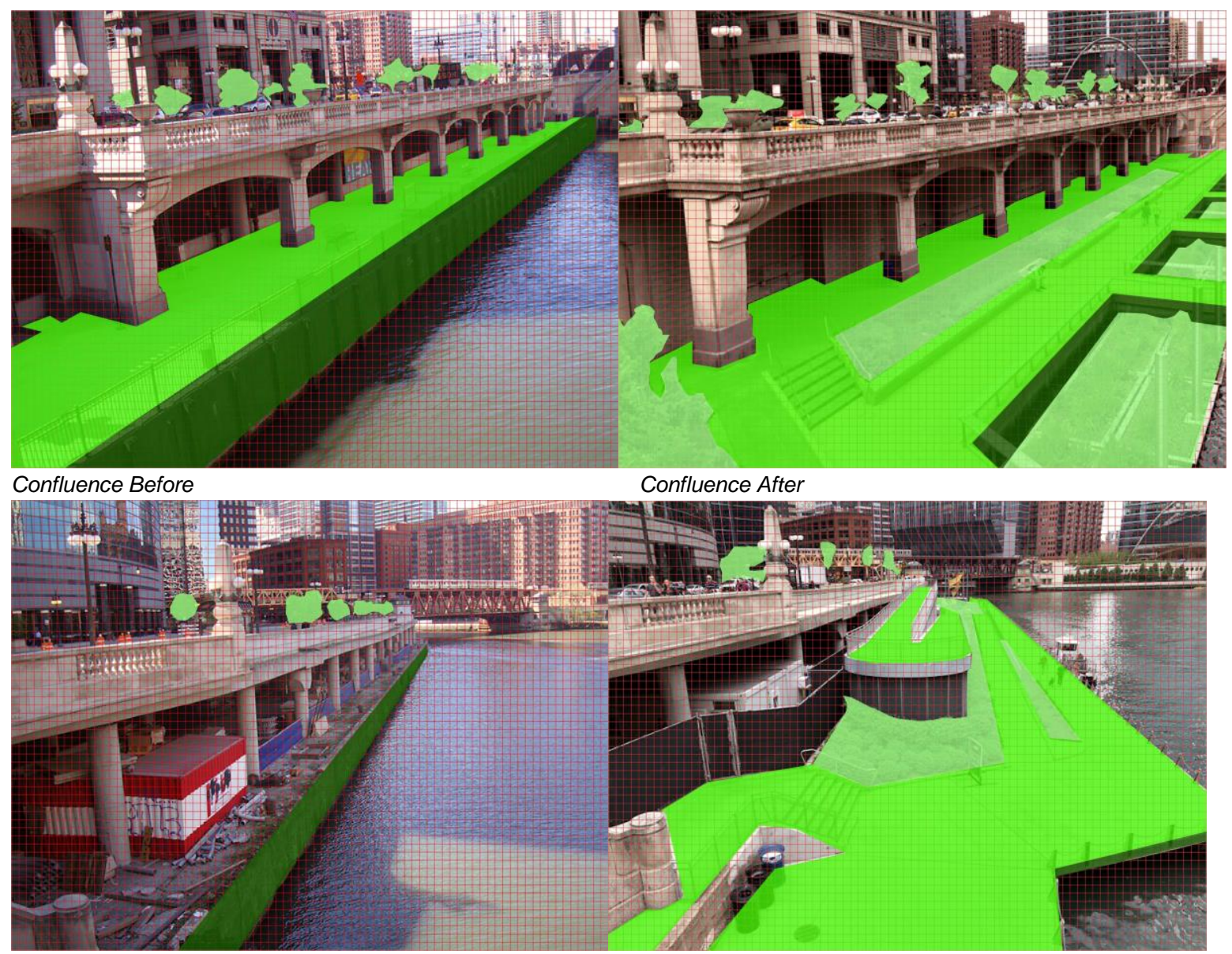

Figure 5: Scenic Quality Index* area takeoffs of the before and after conditions of the Chicago Riverwalk. Source: LAF Research Team, Sasaki Associates

'Light green represents vegetation, bright green represents circulation and dark green represents proximity to the river.

\section{Do you find the Chicago Riverwalk to have improved in the quality of any of the following categories? (Please select all that apply)}

\begin{tabular}{|l|r|r|}
\hline Aesthetic & 26 & $52 \%$ \\
\hline Environmental & 15 & $30 \%$ \\
\hline Cultural & 17 & $34 \%$ \\
\hline Accessibility & 17 & $34 \%$ \\
\hline & & \\
\hline I was not familiar with the site prior to its reconstruction & 15 & $30 \%$ \\
\hline
\end{tabular}

Table 13: User perception in quality of the site as determined by July 4 and 8, 2019 survey. Source: LAF Research Team

\section{Sources:}

BLM's Visual Resource Inventory. Accessed July 29, 2019. http://blmwyomingvisual.anl.gov/vr-inventory/blm/. 
Callone, Matt. Chicago Riverwalk User Survey. July 8, 2019. Raw data. Chicago Riverwalk, Chicago.

Limitations: There is a strong element of subjectivity to visual quality of an image. Furthermore, the analysis is conducted from only one vantage point in each "room," only providing one estimation of a change in scenic quality. For survey limitations, see above.

\section{Economic Benefits}

- Created 170 new seasonal, 125 part-time, and 66 permanent jobs from 2016 to 2019, as reported by 9 surveyed Riverwalk vendors. Of 6 vendors that were on the site before and after the reconstruction, $83 \%$ said that the project made their business more profitable.

The opening of the Chicago Riverwalk Phases 2 and 3 doubled the number of Riverwalk vendors from 5 to 10.5 out of $6(83 \%)$ of the vendors that responded to the survey and have been at the Riverwalk since prior to the reconstruction in 2016 stated that the reconstruction has made their businesses more profitable. One result of an increase in profitability is increased employment opportunities.

Methods: During the month of July 2019, a Google Form survey was distributed by the LAF Research Team to Chicago Riverwalk vendors. Responses were auto-totaled and provided as percentages and individual responses. Vendors were asked how many seasonal, part-time and full-time positions they have added since 2016 (Figure 6). These responses were interpreted in Table 14. They were also asked if their business has been more profitable since the reconstruction. $5 / 6$, or $83 \%$, self-reported that they are more profitable (Figure 7 ). The full vendor survey is found in Appendix $\mathrm{C}$.

\section{Calculations:}

35-part time 35-full time

Approximately 140 . Ninety of which are seasonal

10 part-time - 1 full time - seasonal

Currently - 60 full time seasonal and 20 part time - same last year

1 full time and 25 part time

30

2 full time, 20 full time seasonal

35 - part time; 30 full time

Negligible changes 
Figure 6: Positions added by Chicago Riverwalk vendors since 2016 as self-reported by vendors in July 2019. Source: LAF Research Team Vendor Survey

\begin{tabular}{|l|l|}
\hline Part-time & 125 \\
\hline Seasonal & 170 \\
\hline Full-time & 66 \\
\hline Other & 80 \\
\hline
\end{tabular}

Table 14: Self-reported positions interpreted by LAF Research Team. Source: LAF Research Team

3. If your business was here prior to the reconstruction of the Chicago Riverwalk Phases 2 and 3, how has the r...ted the profitability of your business? 6 responses

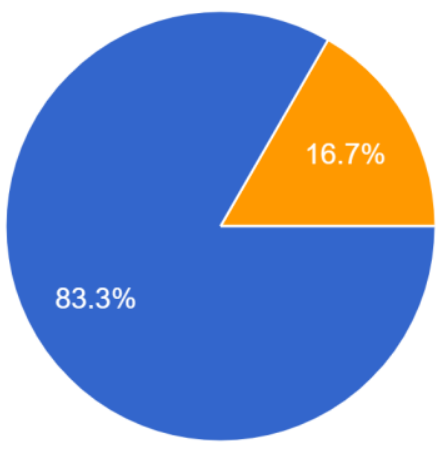

Figure 7: How has the reconstruction affected the profitability of your business?-Vendor responses Source: LAF Research Team.

Sources:

Callone, Matt. Chicago Riverwalk Vendor Survey. July 2019. Raw data. Chicago Riverwalk, Chicago.

\section{Limitations:}

Only 9 out of 11 businesses reported actual numbers for jobs added, so this represents only a portion of jobs added. All business vendors with locations along the Chicago Riverwalk were surveyed since there are residual benefits of the Phase 2 and 3 improvements to vendors adjacent to other portions of the Chicago Riverwalk project.

- Doubled the number of Riverwalk vendors and increased profits by $164 \%$ from 2014 to 2018, with almost $\$ 50$ million in total revenue in $2018.90 \%$ of 50 surveyed visitors reported that they also patronize nearby businesses not along the Riverwalk before or after their visit. 
Methods: The 2017 and 2018 Chicago Riverwalk Financial Plan provided the number of Riverwalk vendors and the metrics of Riverwalk (1) concessionaires and (2) tour boat revenue in 2014 compared to 2018 (Tables 15-18). Tables 15 and 16 show an increase in vendors from 5 in 2014 to 10 in 2018. The percent increase in profits was calculated by using the 2014 preconstruction and 2018 total revenue metrics for all Riverwalk businesses highlighted in yellow in Tables 15-18 (Table 19). Concessionaires' data and tour boat data were combined for the total profits. On July 4 and 8,2019 , Riverwalk visitors were asked in a survey if they patronized other businesses in the area before or after visiting the Riverwalk. Survey results were tallied and taken as a percentage (Table 21). The full survey can be found in Appendix B. See full survey information and limitations in previous benefit sections.

\section{Calculations:}

\begin{tabular}{|l|r|r|r|r|r|}
\hline Concessionaire & $\mathbf{2 0 1 0}$ & $\mathbf{2 0 1 1}$ & $\mathbf{2 0 1 2}$ & $\mathbf{2 0 1 3}$ & 2014 \\
\hline Bike Chicago (lower) & $\$ 92,506$ & $\$ 88,233$ & $\$ 61,505$ & $\$ 14,288$ & $\$ 4,175$ \\
\hline Bike Chicago (upper) & $\$ 5,448$ & $\$ 84,077$ & $\$ 83,198$ & $\$ 33,318$ & $\$ 8,418$ \\
\hline Cyrano's Café and Wine Bar & $\$ 190,868$ & $\$ 232,767$ & $\$ 203,009$ & $\$ 165,423$ & $\$ 273,171$ \\
\hline O'Brien's Riverwalk Café & $\$ 884,493$ & $\$ 790,435$ & $\$ 755,743$ & $\$ 567,314$ & $\$ 629,725$ \\
\hline Tree of Life Juice Bar & & & & $\$ 6,040$ & \\
\hline Urban Kayaks & & $\$ 63,015$ & $\$ 286,903$ & $\$ 294,919$ & $\$ 331,291$ \\
\hline \hline Totals & $\$ 1,173,315$ & $\$ 1,258,528$ & $\$ 1,390,358$ & $\$ 1,081,303$ & $\$ 1,246,780$ \\
\hline
\end{tabular}

As reported by Chicago Park District. The City is unable to guarantee the accuracy of these figures or provide any additional information.

Table 15: Chicago Riverwalk concessionaires' revenue 2010-2014. Source: City of Chicago

\begin{tabular}{|c|c|c|c|c|c|c|c|c|c|c|c|c|c|c|c|}
\hline \multicolumn{16}{|c|}{ Chicago Riverwalk Financial Report } \\
\hline \multicolumn{16}{|c|}{ F/Y 2018} \\
\hline Vendor & \multicolumn{2}{|r|}{ Total Revenue } & \multicolumn{2}{|r|}{ Taxes } & Gross Sales & \multirow{2}{*}{\begin{tabular}{|l|} 
Percent \\
$2.0 \%$
\end{tabular}} & $\begin{array}{c}\text { Actual } \\
\text { Percent Fee }\end{array}$ & $\begin{array}{c}\text { Projected } \\
\text { Percentage Fee }\end{array}$ & \multirow{2}{*}{\begin{tabular}{|l|} 
Difference \\
$(2,508.95)$
\end{tabular}} & \multicolumn{2}{|r|}{$\begin{array}{c}\text { Annual } \\
\text { License Fee }\end{array}$} & \multicolumn{2}{|c|}{$\begin{array}{c}\text { Actual Percent } \\
\text { Fee }\end{array}$} & \multicolumn{2}{|c|}{\begin{tabular}{|c} 
Total Annual and \\
Percent Fee
\end{tabular}} \\
\hline Urban Kayaks & $\$$ & $680,764.25$ & $\$$ & $56,211.75$ & $624,552.50$ & & $\$ 12,491.05$ & $15,000.00$ & & $\$$ & $30,000.00$ & $\$$ & $12,491.05$ & $\$$ & $42,491.05$ \\
\hline Island Party Hut & $\$$ & $2,044,314.20$ & $\$$ & $204,573.30$ & $1,839,740.90$ & $7.0 \%$ & $\$ 128,781.86$ & $184,856.00$ & $(56,074.14)$ & $\$$ & $37,502.00$ & $\$$ & $128,781.86$ & $\$$ & $166,283.86$ \\
\hline Northman & $\$$ & $196,938.80$ & $\$$ & $20,303.88$ & $176,634.92$ & $0.0 \%$ & $\$ \quad-$ & - & 0.00 & $\$$ & - & $\$$ & - & & \\
\hline O'Briens & $\$$ & $2,065,185.85$ & $\$$ & $215,729.50$ & $1,849,456.35$ & $8.0 \%$ & $\$ 147,956.51$ & $144,000.00$ & $3,956.51$ & $\$$ & $50,475.00$ & $\$$ & $147,956.51$ & $\$$ & $198,431.51$ \\
\hline Chicago Brew House & $\$$ & $857,307.87$ & $\$$ & $87,049.30$ & $770,258.57$ & $5.0 \%$ & $\$ 38,512.93$ & $60,000.00$ & $(21,487.07)$ & $\$$ & $23,334.00$ & $\$$ & $38,512.93$ & $\$$ & $61,846.93$ \\
\hline City Winery & $\$$ & $5,438,646.30$ & $\$$ & $544,740.72$ & $4,893,905.58$ & $10.0 \%$ & $\$ 489,390.56$ & $320,000.00$ & $169,390.56$ & $\$$ & $60,000.00$ & $\$$ & $489,390.56$ & $\$$ & $549,390.56$ \\
\hline Tiny Tapp & $\$$ & $2,313,130.72$ & $\$$ & $235,904.86$ & $2,077,225.86$ & $4.0 \%$ & $\$ 83,089.03$ & $92,000.00$ & $(8,910.97)$ & $\$$ & $23,743.50$ & $\$$ & $83,089.03$ & $\$$ & $106,832.53$ \\
\hline Chicago Water Taxi & $\$$ & $42,127.30$ & $\$$ & - & $42,127.30$ & $5.0 \%$ & $\$ 2,106.37$ & $2,602.50$ & (496.14) & $\$$ & $18,003.00$ & $\$$ & $2,106.37$ & $\$$ & $20,109.37$ \\
\hline Downtown Docks & $\$$ & $636,420.30$ & $\$$ & $58,935.59$ & $577,484.71$ & $5.0 \%$ & $\$ 28,874.24$ & $18,256.25$ & $10,617.99$ & $\$$ & $19,500.00$ & $\$$ & $28,874.24$ & $\$$ & $48,374.24$ \\
\hline Frost Gelato & $\$$ & $120,348.81$ & $\$$ & $12,533.32$ & $107,815.49$ & $3.5 \%$ & $\$ \quad 3,773.54$ & $6,921.25$ & $(3,147.71)$ & $\$$ & $14,004.80$ & $\$$ & $3,773.54$ & $\$$ & $17,778.34$ \\
\hline To & & $14,395,184.40$ & & $1,435,982.22$ & $\$ 12,959,202.18$ & & $\$ 934,976.08$ & & $91,340.08$ & $\$$ & $276,562.30$ & $\$$ & $934,976.08$ & $\$$ & $1,211,538.38$ \\
\hline
\end{tabular}

Table 16: Chicago Riverwalk concessionaires' revenue 2018. Source: City of Chicago 


\begin{tabular}{|c|c|c|c|c|c|c|}
\hline \multicolumn{7}{|c|}{ Historical Riverwalk Revenues } \\
\hline \multirow[b]{2}{*}{ Year } & \multicolumn{2}{|c|}{ Tourboat Operator Revenue } & \multicolumn{4}{|c|}{ Tourboat Rent Revenue } \\
\hline & Location 1 & Location $2^{*}$ & \multicolumn{2}{|c|}{ Location 1} & \multicolumn{2}{|c|}{ Location 2} \\
\hline 1993 & $\$ \quad 1,388,780$ & -- & & $n / a^{* \star}$ & & $\mathrm{n} / \mathrm{a}^{\star \star}$ \\
\hline 1994 & $1,664,865$ & .- & & $\mathrm{n} / \mathrm{a}^{* *}$ & & $\mathrm{n} / \mathrm{a}^{* *}$ \\
\hline 1995 & $1,732,841$ & -- & & $n / a^{* *}$ & & $n / a^{* \star}$ \\
\hline 1996 & $1,793,841$ & -- & & $n / a^{* *}$ & & $\mathrm{n} / \mathrm{a}^{* \star}$ \\
\hline 1997 & $1,752,058$ & -- & & $n / a^{* \star}$ & & $n / a^{\star *}$ \\
\hline 1998 & $2,254,917$ & -- & & $n / a^{* \star}$ & & $\mathrm{n} / \mathrm{a}^{* \star}$ \\
\hline 1999 & $2,417,083$ & -- & & $n / a^{* *}$ & & $\mathrm{n} / \mathrm{a}^{\star *}$ \\
\hline 2000 & $2,923,194$ & -- & & $n / a^{* *}$ & & $n / a^{* \star}$ \\
\hline 2001 & $2,343,594$ & -- & & $n / a^{* *}$ & & $n / a^{* *}$ \\
\hline 2002 & $2,716,161$ & $3,941,076$ & & $n / a^{* *}$ & & $n / a^{* *}$ \\
\hline 2003 & $2,885,365$ & $4,126,781$ & & $n / a^{* *}$ & & $\mathrm{n} / \mathrm{a}^{\star \star}$ \\
\hline 2004 & $2,993,212$ & $4,321,237$ & & $n / a^{\star \star}$ & & $\mathrm{n} / \mathrm{a}^{\star \star}$ \\
\hline 2005 & $3,233,183$ & $4,524,856$ & & $n / a^{* *}$ & & $n / a^{* *}$ \\
\hline 2006 & $3,608,971$ & $4,738,069$ & & $n / a^{* *}$ & & $n / a^{* \star}$ \\
\hline 2007 & $4,368,915$ & $4,961,328$ & & $n / a^{* \star}$ & & $n / a^{* *}$ \\
\hline 2008 & $4,756,454$ & $5,195,108$ & & $n / a^{* *}$ & & $\mathrm{n} / \mathrm{a}^{\star \star}$ \\
\hline 2009 & $4,675,849$ & $5,439,904$ & & $\mathrm{n} / \mathrm{a}^{* *}$ & & $\mathrm{n} / \mathrm{a}^{\star \star}$ \\
\hline 2010 & $5,275,685$ & $5,696,235$ & $\$$ & 156,656 & $\$$ & 223,349 \\
\hline 2011 & $6,681,184$ & $5,964,644$ & $\$$ & 161,355 & $\$$ & 234,517 \\
\hline 2012 & $7,228,322$ & $6,245,700$ & $\$$ & 169,423 & $\$$ & 281,420 \\
\hline 2013 & $7,734,305$ & $6,540,000$ & $\$$ & $1,282,051$ & $\$$ & 877,592 \\
\hline 2014 & $8,353,049$ & $6,834,300$ & $\$$ & $1,366,239$ & $\$$ & 873,647 \\
\hline \multicolumn{7}{|c|}{ * Location 2 added in 2002} \\
\hline ** Not available & & & & & & \\
\hline Source: CDOT & & & & & & \\
\hline
\end{tabular}

Table 17: Chicago Riverwalk tour boat revenue 1993-2014. Source: City of Chicago

Location One: Mercury Skyline Cruiseline-Chicago's First Lady

\begin{tabular}{|c|c|c|c|c|c|c|c|c|c|c|c|c|c|c|c|c|}
\hline \multicolumn{17}{|c|}{ Chicago Riverwalk Tour Boats Concessions } \\
\hline \multirow{2}{*}{\multicolumn{17}{|c|}{$\begin{array}{l}\text { Mercury Skyline Cruiseline - Chicago First Lady } \\
F / Y 2018\end{array}$}} \\
\hline & & & & & & & & & & & & & & & & \\
\hline Fiscal Year & \multicolumn{2}{|r|}{ Total Revenues } & \multirow{2}{*}{\multicolumn{2}{|c|}{ Deductions }} & \multirow{2}{*}{\multicolumn{2}{|c|}{\begin{tabular}{cl}
\multicolumn{2}{c}{ Gross Sales } \\
$\$$ & $11,641,018.60$
\end{tabular}}} & \multirow{2}{*}{\begin{tabular}{|l} 
Percent \\
$5.0 \%$
\end{tabular}} & \multicolumn{2}{|c|}{$\begin{array}{l}\text { Actual Percent } \\
\text { Fee }\end{array}$} & $\begin{array}{c}\text { Projected } \\
\text { Percentage Fee } \\
\end{array}$ & \multirow{2}{*}{$\begin{aligned} \text { Difference } \\
45,355.93\end{aligned}$} & \multicolumn{2}{|c|}{$\begin{array}{c}\text { Annual License } \\
\text { Fee }\end{array}$} & $\begin{array}{c}\text { Actual Percent } \\
\text { Fee }\end{array}$ & \multicolumn{2}{|c|}{\begin{tabular}{|c} 
Total Annual and \\
Percent Fee
\end{tabular}} \\
\hline 2013 & & & & & & & & $\$$ & $582,050.93$ & $\$ \quad 536,695.00$ & & $\$$ & $700,000.00$ & $\$ \quad 582,050.93$ & $\$$ & $1,282,050.93$ \\
\hline 2014 & $\$$ & $22,003,313.00$ & $\$$ & $9,028,781.85$ & $\$$ & $12,974,531.15$ & $5.0 \%$ & $\$$ & $648,726.56$ & $579,630.00$ & $69,096.56$ & $\$$ & $721,000.00$ & $648,726.56$ & $\$$ & $1,369,726.56$ \\
\hline 2015 & $\$$ & $26,443,390.13$ & $\$$ & $10,385,583.11$ & $\$$ & $16,057,807.02$ & $5.0 \%$ & $\$$ & $802,890.35$ & $648,726.56$ & $154,163.79$ & $\$$ & $742,630.00$ & $802,890.35$ & $\$$ & $1,545,520.35$ \\
\hline 2016 & $\$$ & $29,222,004.75$ & $\$$ & $11,641,646.39$ & $\$$ & $17,580,358.36$ & $5.0 \%$ & $\$$ & $879,017.92$ & $769,981.00$ & $109,036.92$ & $\$$ & $764,909.00$ & $879,017.92$ & $\$$ & $1,643,926.92$ \\
\hline 2017 & $\$$ & $29,737,540.62$ & $\$$ & $11,877,468.19$ & $\$$ & $17,860,072.43$ & $5.0 \%$ & $\$$ & $893,003.62$ & $831,579.00$ & $61,424.62$ & $\$$ & $787,856.00$ & $893,003.62$ & $\$$ & $1,680,859.62$ \\
\hline 2018 & $\$$ & $29,830,327.65$ & $\$$ & $11,239,623.69$ & $\$$ & $18,590,703.96$ & $5.0 \%$ & $\$$ & $929,535.20$ & $898,106.00$ & $31,429.20$ & $\$$ & $811,492.00$ & $929,535.20$ & $\$$ & $1,741,027.20$ \\
\hline тот & $\$$ & $137,236,576.15$ & $\$$ & $54,173,103.23$ & $\$$ & $83,063,472.92$ & & & $4,153,173.65$ & & $\$ 470,507.02$ & & $3,827,887.00$ & $\$ 4,153,173.65$ & $\$$ & $7,981,060.65$ \\
\hline
\end{tabular}

Location Two: Wendella Sightseeing Boats

\begin{tabular}{|c|c|c|c|c|c|c|c|c|c|c|c|c|c|c|c|c|}
\hline \multicolumn{17}{|c|}{ Chicago Riverwalk Tour Boats Concessions } \\
\hline \multicolumn{17}{|c|}{ Wendella Sightseeing Company } \\
\hline \multicolumn{17}{|c|}{ F/Y 2018} \\
\hline Fiscal Year & \multicolumn{2}{|c|}{ Total Revenues } & Deductions & \multicolumn{2}{|r|}{ Gross Sales } & Percent & \multicolumn{2}{|c|}{$\begin{array}{l}\text { Actual Percent } \\
\text { Fee }\end{array}$} & $\begin{array}{c}\text { Projected } \\
\text { Percentage Fee }\end{array}$ & \multirow{2}{*}{$\frac{\text { Difference }}{(58.00)}$} & \multicolumn{2}{|c|}{$\begin{array}{c}\text { Annual License } \\
\text { Fee }\end{array}$} & \multicolumn{2}{|c|}{$\begin{array}{c}\text { Actual Percent } \\
\text { Fee }\end{array}$} & \multicolumn{2}{|c|}{$\begin{array}{c}\text { Total Annual and } \\
\text { Percent Fee }\end{array}$} \\
\hline 2013 & $\$$ & $6,538,066.66$ & & $\$$ & $6,538,066.66$ & $3.0 \%$ & $\$$ & $196,142.00$ & $\$ \quad 196,200.00$ & & $\$$ & $681,450.00$ & $\$$ & $196,142.00$ & $\$$ & $877,592.00$ \\
\hline 2014 & $\$$ & $5,668,324.00$ & $\$$ & $\$$ & $5,668,324.00$ & $3.0 \%$ & $\$$ & $170,049.72$ & $205,029.00$ & $(34,979.28)$ & $\$$ & $703,597.13$ & $\$$ & $170,049.72$ & $\$$ & $873,646.85$ \\
\hline 2015 & $\$$ & $5,212,515.00$ & $\$$ & $\$$ & $5,212,515.00$ & $3.0 \%$ & $\$$ & $156,375.45$ & $214,255.31$ & $(57,879.86)$ & $\$$ & $726,464.04$ & $\$$ & $156,375.45$ & $\$$ & $882,839.49$ \\
\hline 2016 & $\$$ & $5,823,340.00$ & - & $\$$ & $5,823,340.00$ & $3.0 \%$ & $\$$ & $174,700.20$ & $223,896.79$ & $(49,196.59)$ & $\$$ & $750,074.11$ & $\$$ & $174,700.20$ & $\$$ & $924,774.31$ \\
\hline 2017 & $\$$ & $5,674,137.00$ & $\$$ & $\$$ & $5,674,137.00$ & $3.0 \%$ & $\$$ & $170,224.11$ & $233,972.15$ & $(63,748.04)$ & $\$$ & $744,451.52$ & $\$$ & $170,224.11$ & $\$$ & $914,675.63$ \\
\hline \multirow[t]{2}{*}{2018} & $\$$ & $5,094,096.00$ & $\$$ & $\$$ & $5,094,096.00$ & $3.0 \%$ & $\$$ & $152,822.88$ & $244,500.90$ & $(91,678.02)$ & $\$$ & $799,621.20$ & $\$$ & $152,822.88$ & $\$$ & $952,444.08$ \\
\hline & $\$$ & $27,472,412.00$ & $\$$ & $\$$ & $27,472,412.00$ & & $\$$ & $824,172.36$ & & $\$(297,481.79)$ & & $3,724,208.00$ & $\$$ & $824,172.36$ & $\$$ & $4,548,380.36$ \\
\hline
\end{tabular}

Table 18: Chicago Riverwalk tour boat revenue 2013-2018. Source: City of Chicago 


\begin{tabular}{|c|r|c|c|}
\hline Year & Concessionaires & \multicolumn{1}{|c|}{ Tour boats } & \multicolumn{1}{c|}{ TOTAL } \\
\hline 2014 & $\$ 1,246,780.00$ & $\$ 17,427,235.00$ & $\$ 18,674,015.00$ \\
\hline 2018 & $\$ 14,395,184.40$ & $\$ 34,924,560.65$ & $\$ 49,319,745.05$ \\
\hline & & Dollar Increase & $\$ 30,645,730.05$ \\
\hline & & $\begin{array}{l}\text { Percent } \\
\text { Increase }\end{array}$ & $\mathbf{1 6 4 . 1 1} \%$ \\
\hline
\end{tabular}

Table 19: Increase in Chicago Riverwalk Business Revenue calculated from Tables 16-19.

Source: City of Chicago

5. Before or after visiting the Riverwalk, do you ever patronize businesses in the area not along the Riverwalk? If so, which type?(i.e. restaurants, bars, recreation) (Please select all that apply)

\begin{tabular}{|l|r|r|}
\hline Restaurant & 32 & $64 \%$ \\
\hline Bar & 25 & $50 \%$ \\
\hline Recreation & 13 & $26 \%$ \\
\hline Retail & 12 & $24 \%$ \\
\hline $\begin{array}{l}\text { I do not spend money at any of the businesses in the area when } \\
\text { visiting the Riverwalk. }\end{array}$ & 5 & $10 \%$ \\
\hline & $50 / 50$ & \\
\hline
\end{tabular}

Table 20: Spending habits in the vicinity of the Chicago Riverwalk as self-reported on July 4 and 8, 2019. Source: LAF Research Team User Survey

Sources:

Callone, Matt. Chicago Riverwalk Vendor Survey. July 2019. Raw data. Chicago Riverwalk, Chicago.

Chicago Riverwalk Financial Plan as of December 31, 2017. PDF. Chicago: City of Chicago, March 30, 2018.

Chicago Riverwalk Financial Plan as of December 31, 2018. PDF. Chicago: City of Chicago, March 29, 2019.

Limitations: The City of Chicago cannot confirm the accuracy of data sourced by the Chicago Parks District.

- Catalyzed over \$12 million in funding for the redevelopment of earlier phases of the Riverwalk including the creation of a Master Plan for older portions of the Riverwalk and over $\$ \mathbf{2 4 0 , 0 0 0}$ for the construction of a Community Marketplace. 
As a result of the economic success of the concessions program, the City of Chicago decided not to pursue hiring a Master Developer and instead maintains the Chicago Department of Fleet and Facility Management (2FM) as the property manager and the Chicago Department of Cultural Affairs and Events (DCASE) for program oversight. Beyond keeping property management as an in-house expenditure, the success of Chicago Riverwalk concessions programming provides an impetus for redevelopment of older portions of the Riverwalk. The Community Marketplace is expected to be completed in the summer of 2018. The Master Plan for redevelopment of the pre-Phase 1 area includes a new path, additional landscaping, lighting, and public seating.

Methods: The 2018 Chicago Riverwalk Financial Plan details the identification of funding for the redevelopment of the pre-Phase 1 portion of the Chicago Riverwalk between Michigan Avenue and Lake Shore Drive.

Calculations:

The 2018 Chicago Riverwalk Financial Plan identifies that $\$ 242,136.50$ was allocated for the creation of a new Marketplace, and $\$ 12$ million was allocated for Riverwalk improvements in 2019.

Sources:

Chicago Riverwalk Financial Plan as of December 31, 2018. PDF. Chicago: City of Chicago, March 29, 2019.

Limitations: Catalyzation of the redevelopment of pre-Phase 1 cannot be definitively attributed to the success of Phases 2 and 3 , but it is highly likely that Phases 2 and 3 played a direct role.

- Generated approximately \$16 million from 2013 to 2018 toward the repayment of a $\$ 99$ million federal loan used for project construction. Revenues designated for loan repayment generated from Riverwalk concessions were an average of $29 \%$ higher than projected.

A federal Transportation Infrastructure Finance and Innovation program loan (TIFIA) was used for construction of the Riverwalk. Repayment was scheduled to occur through city revenues generated primarily from concessions on the Riverwalk including license fees, advertising, and sponsorships. The Riverwalk has exceeded revenue projections, putting the City ahead of schedule for TIFIA loan repayment.

Methods: Data was collected from Figure 3b of the 2018 Chicago Riverwalk Financial Plan's listed metrics of project revenue collected since 2013 from concessions along the riverfront, consisting of tour boats and vendors. Pledged revenues primarily collected through license fees generated from 2013 to 2018 were summated to determine total repayment as of the end of the 2018 fiscal year. The average percent differences from the expected revenues between 2014 and 2018 were calculated (Table 21). On average, this amount exceeded projected revenue for the repayment schedule by $29 \%$. 
Calculations:

\begin{tabular}{|l|c|c|c|r|}
\hline Year & Likely & Actual & $\begin{array}{c}\text { Difference from } \\
\text { Likely }\end{array}$ & $\begin{array}{l}\text { Percent } \\
\text { Difference }\end{array}$ \\
\hline 2014 & $\$ 1,381,450.00$ & $\$ 2,220,192.93$ & $\$ 838,742.93$ & $60.71 \%$ \\
\hline 2015 & $\$ 2,164,128.19$ & $\$ 2,724,708.25$ & $\$ 560,580.06$ & $25.90 \%$ \\
\hline 2016 & $\$ 2,657,898.09$ & $\$ 3,362,459.88$ & $\$ 704,561.79$ & $26.51 \%$ \\
\hline 2017 & $\$ 3,269,726.04$ & $\$ 3,819,952.33$ & $\$ 550,226.29$ & $16.83 \%$ \\
\hline 2018 & $\$ 3,401,569.28$ & $\$ 3,905,009.66$ & $\$ 503,440.38$ & $14.80 \%$ \\
\hline & $\begin{array}{l}\text { Amount } \\
\text { Repaid }\end{array}$ & $\$ 16,032,323.05$ & $\begin{array}{l}\text { Percent in Excess } \\
\text { of Expectations }\end{array}$ & $\mathbf{2 8 . 9 5 \%}$ \\
\hline
\end{tabular}

Table 21: Annual Riverwalk Revenue Calculations. Source: City of Chicago

Sources:

Chicago Riverwalk Financial Plan as of December 31, 2017. PDF. Chicago: City of Chicago, March 30, 2018.

Chicago Riverwalk Financial Plan as of December 31, 2018. PDF. Chicago: City of Chicago, March 29, 2019.

Limitations: The TIFIA loan accrues interest. The amount repaid must be compared to the outstanding balance including interest to understand the proportion of debt paid to date.

- Supports investment in public art, with over $\$ 460,000$ designated for programming and public art in 2018 and over \$2 million designated for an international art competition in 2019.

The Chicago Department of Cultural Affairs and Events (DCASE) oversees Riverwalk Programming and a Public Art campaign on the Chicago Riverwalk. The Department of Fleet and Facility Management (2FM) and DCASE work alongside one another to provide events that are culturally relevant for Chicago citizens and tourists alike. In 2017 and 2018, \$462,080 was provided for programming and public art expenditures. In 2019, DCASE launched an international call to artists for a public art design competition, providing $\$ 40,000$ for finalists' development proposals and $\$ 2$ million for the design and construction of the selected piece.

Methods: The 2018 Chicago Riverwalk Financial Plan provided programming and public art expenditures for 2017 and 2018, as well as the money allocation in 2019 for the public art piece to be displayed as part of the Riverwalk East Gateway Project (Table 22) 
Calculations:

\begin{tabular}{|c|c|c|c|c|c|c|}
\hline Year & $\begin{array}{l}\text { Contract } \\
\text { Property } \\
\text { Management }\end{array}$ & \begin{tabular}{|l} 
Facility \\
Operations \\
Work Orders
\end{tabular} & $\begin{array}{l}\text { Capital } \\
\text { Projects }\end{array}$ & $\begin{array}{l}\text { Public Art \& } \\
\text { Programming }\end{array}$ & $\begin{array}{l}\text { Special } \\
\text { Projects }\end{array}$ & Total \\
\hline 2015 & $\$ \quad 663,503.05$ & $\$$ & & & & \\
\hline 2016 & $\$ 1,004,756.28$ & $\$$ & & & & \\
\hline 2017 & $\$ 2,284,419.85$ & $\$ 305,158.95$ & $\$ 160,064.56$ & $\$ 130,158.95$ & & $\$ 2,879,802.31$ \\
\hline 2018 & $\$ 2,071,325.60$ & $\$ 250,370.00$ & $\$ 494,314.41$ & $\$ 331,920.00$ & $\$ 23,889.56$ & $\$ 3,171,819.57$ \\
\hline
\end{tabular}

Table 22: Expenditures dedicated to public art and programming. Source: Chicago Riverwalk Financial Plan.

\section{Sources:}

Chicago Riverwalk Financial Plan as of December 31, 2018. PDF. Chicago: City of Chicago, March 29, 2019.

Limitations: Not all investments in public art are quantified in the 2017 and 2018 Chicago Riverwalk Financial Plans, such as the Arts in the Dark Halloween Parade, or Art on the MART's permanent projection system (which displays art on the 2.5 acre Merchandise Mart river facade for five nights a week, 10 months of the year).

\section{Inconclusive Benefits}

\section{- Increased the availability of quality aquatic habitat as demonstrated by 15 species of fish identified along the Chicago Riverwalk.}

Whereas approximately 40 years ago only seven fish were identified in the Chicago River, today the Friends of the Chicago River has identified around 70 different species of fish, including the first recorded sighting of the American Eel in the Chicago River in 2014. This rebound in aquatic life is the result of decades of improvements in water quality and the reestablishment of habitat. Inspired by the Friends of the Chicago River's floating garden that functioned as a "fish hotel" on the Riverwalk site in 2005, the floating wetlands contain fish habitat structures including fish lunkers for resting areas and protection and limnetic caisson curtains that encourage algae formation on the nylon strands, which serve as a food source for fish. Plantings in the stainless steel floating gardens are both native emergent and submergent species that provide habitats for invertebrates that in turn are used as food for fish, amphibians, ducks, and other wildlife (Figure 8). The floating wetland plays a role in the larger ecology of the Chicago River by supporting aquatic populations moving through the main branch of the River; the wetlands greatest contribution is its use as an observation grounds for how to provide opportunities to better support these populations. 


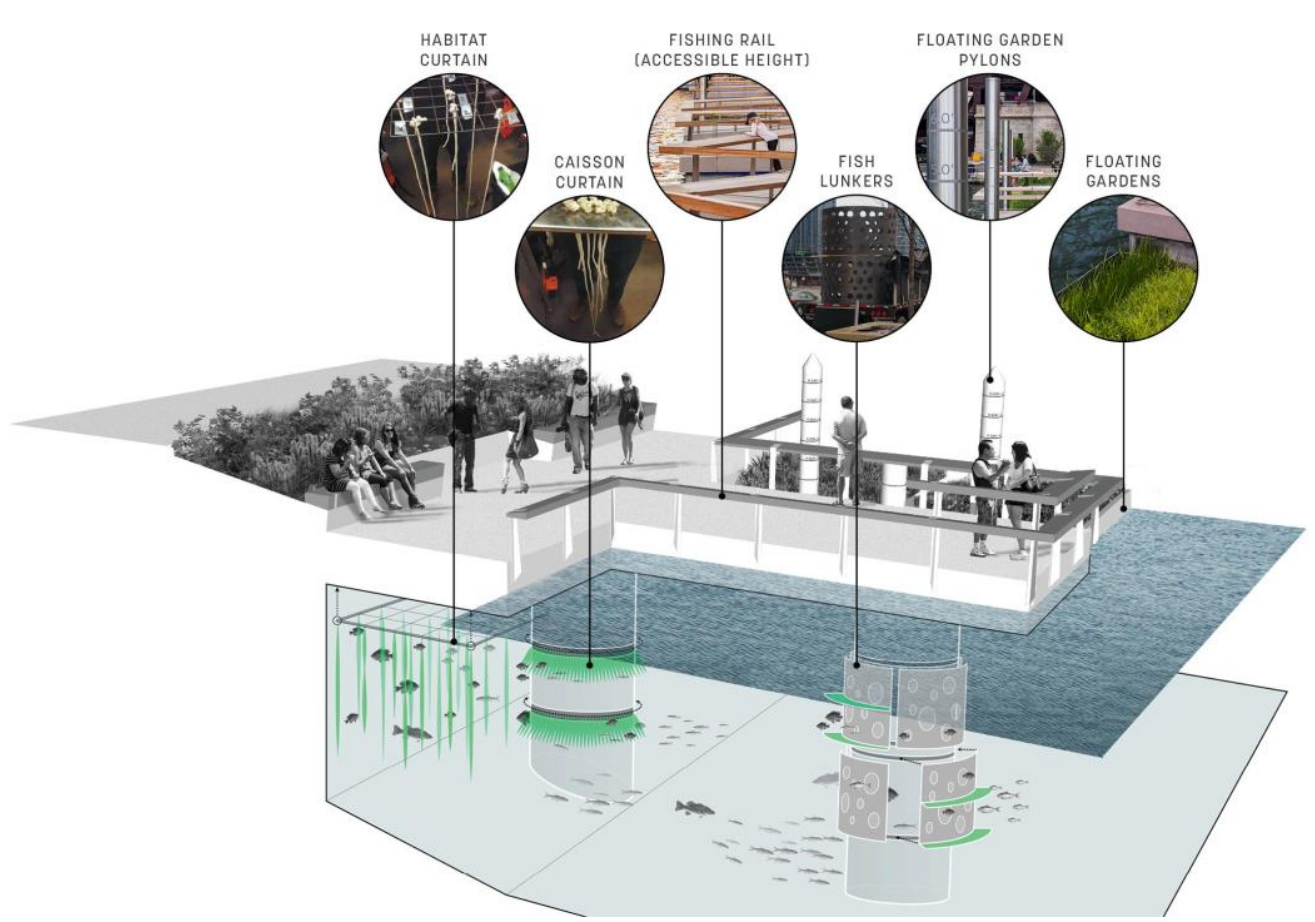

Figure 8: Section diagram of The Jetty room floating wetland

\section{Method:}

On October 20, 2017, a University of Michigan (UM) research team installed an underwater camera within the main branch of the Chicago River along where the Chicago Riverwalk is located to observe fish around and below the floating wetlands at "The Jetty" room of the Riverwalk. In addition, onsite surveys taken by UM students at the Riverwalk from August 1721, 2017 asked surveyees if they fish and which species they typically catch. Photographed recordings and self-reported surveyees identified carp, catfish, bluegill, yellow perch, white perch, bullheads, largemouth, smallmouth and European bass, pinfish, invasive goby, bluegill, bream, crappie, and sunfish. A select number of species of plants found in the floating wetlands listed on construction documents were cross-referenced to determine specific benefits to aquatic life (Table 23).

\section{Calculations:}

Of the six surveyees out of 346 surveyed by UM students that responded "Yes" to "Do you fish here [the Riverwalk]" three fished almost every day, two respondents fished one to three times per month and one respondent fished four to six times per month. The answers to the openended question, "What do you typically catch?" were "carp," "catfish," "bluegill," "yellow perch," "white perch," "bullheads," "largemouth bass," "bass," "pinfish," "invasive goby," "European bass." Desirable species observed in this section of the Chicago Riverwalk, as reported by the UM report, are largemouth and smallmouth bass, bluegill bream, crappie, and sunfish. Fishermen observations and UM reported observations total 15 species of fish identified along the Chicago Riverwalk. 


\begin{tabular}{|l|l|l|}
\hline \multicolumn{3}{|c|}{ Habitat Benefits of Select Species Found in Floating Wetlands } \\
\hline Species & Scientific Name & Habitat Benefit \\
\hline white water lily & Nymphaea odorata & attract invertebrate (i.e. fish food) \\
\hline lizards tail & Saururus cernuus & attract invertebrate (i.e. fish food) \\
\hline palm sedge & Carex muskingumensis & fish protection \\
\hline sweet flag & Acorus calumus & spawning habitat \\
\hline common water plantain & Alisma subcordatum & shade \\
\hline
\end{tabular}

Table 23: Habitat benefits of select species found in floating wetlands. Source: Various

\section{Sources:}

"Help Friends Continue to Improve the Chicago River." Fish - River Ecology and Wildlife - About the River - Friends of the Chicago River. Accessed June 29, 2019.

https://www.chicagoriver.org/about-the-river/river-ecology-and-wildlife/fishes.

Hsieh, Ho, Xuehan Li, Shui Wang, and Yifei Wu. "Post-Occupancy Evaluation of the Chicago Riverwalk." Master's thesis, University of Michigan, 2018. April 2018. Accessed May 29, 2018. http://hdl.handle.net/2027.42/143161.

"Young Angler Catches Rare American Eel at Chicago River Fishing Event." WTTW News. October 17, 2017. Accessed June 29, 2019.

https://news.wttw.com/2017/10/17/young-angler-catches-rare-american-eel-chicago-river -fishing-event.

Limitations: Though species of fish have been identified within the main branch of the Chicago River and the "Jetty" room in particular, University of Michigan (UM) sediment toxicity tests revealed sediment chemically contaminated higher than tolerable to benthic species. The risk of suspended sediment may discourage aquatic life from establishing permanent habitat in the main branch of the river. On October 20, 2017, a UM research team, with the assistance of the Metropolitan Water Reclamation District, collected one-liter sediment samples from the Chicago River at four Ambient Water Quality Monitoring (AWQM) stations, one in the vicinity of the Chicago Riverwalk (station 100), using a Petite Ponar Peterson. Sediment toxicity (Hyalella azteca 7 day survival test) and physiochemical (trace metals) analyses were conducted in the Burton Ecotoxicology Research Laboratory at the School for Environment and Sustainability at the University of Michigan. These analyses revealed sediment heavy metal toxicity and reduced survival rates of Hyalella azteca. Such results suggest that the floating wetlands are not an ideal site for permanent aquatic habitat and support reports by Chicago Fleet and Facilities Management (2FM) of pulling dead fish out of the water. (Though dead fish cannot be solely contributed to potential sediment toxicity, as other urban conditions such as significant boat traffic, water pollution, fishing and other human activities characteristic of a highly urban environment have a large impact on fish populations as well.) Further in-depth studies are 
necessary to have a greater understanding of the impacts of sediment toxicity on aquatic life. As such, this benefit is inconclusive.

\section{- Provides approximately 93\% of the River Theater room's irrigation needs in the month of July via a 2,000-gallon cistern.}

In the River Theater, a 2,000-gallon cistern housed below grade serves as a water reserve to further supplement the room's irrigation needs in drier times. The cistern alone can store approximately 93\% of the River Theater room's irrigation needs, and is it set up to fill with city water when rainwater reserves are low.

Methods: The 2,000-gallon cistern in the River Theater is filled through a pump from catch basins at the base of the room's bottom landing, which drain the area below the planters via a slot drain. CNT equation inputs for bioretention and infiltration were utilized to determine the amount of rainwater that falls onto the River Theater cistern drainage area; the drainage factor equation input for the cistern drainage area was equal to the percentage of the room's surface area that drains to the cistern. The River Theater itself requires an estimated 2,100 gallons in the month of July - the 2000 -gallon cistern alone could meet approximately $93 \%$ of those watering needs.
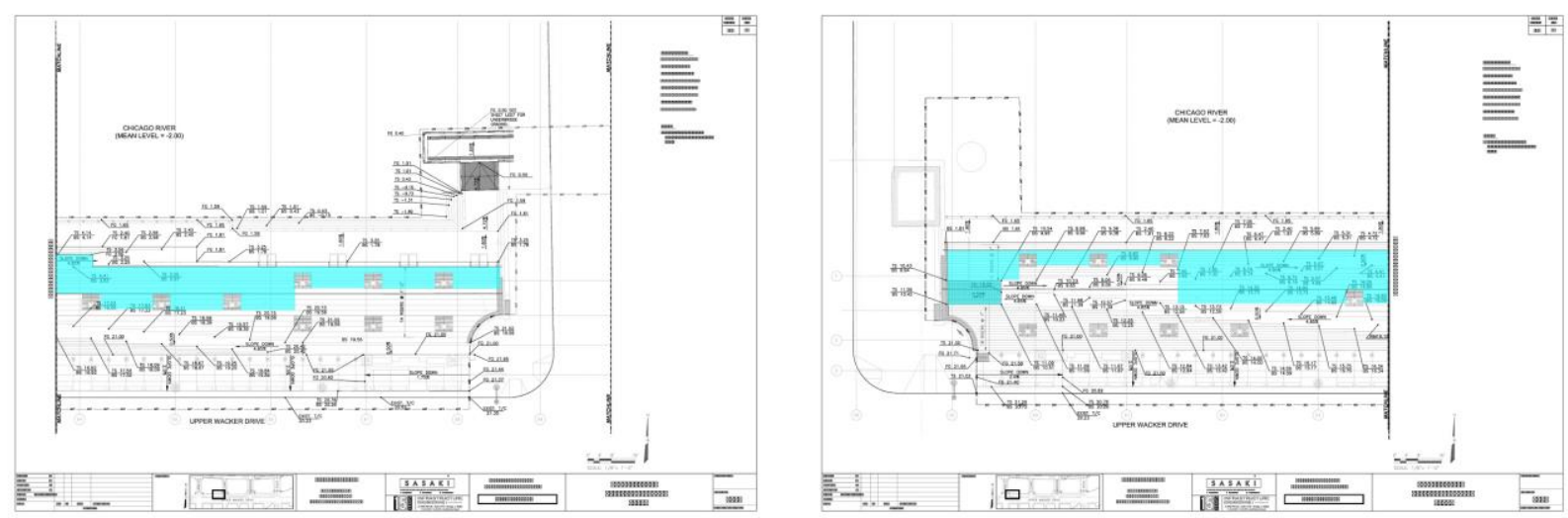

Figure 9: Diagram of River Theater drainage area to cistern

\section{Calculations:}

Cistern Capture: [July precipitation (in) * (cistern drainage area (sf)] * \% of rainfall captured] * $144 \mathrm{sq}$ inches $/ \mathrm{SF}$ * $0.00433 \mathrm{gal} / \mathrm{cubic}$ inch = total runoff reduction (gal)

\begin{tabular}{|l|l|l|l|l|l|l|}
\hline $\begin{array}{l}\text { RUNOFF } \\
\text { DRAINED TO } \\
\text { 2000 GALLON } \\
\text { CISTERN }\end{array}$ & $\begin{array}{l}\text { July } \\
\text { Precipitation }\end{array}$ & $\begin{array}{l}\text { Drainage } \\
\text { Area }\end{array}$ & $\begin{array}{l}\text { Detention } \\
\text { Factor }\end{array}$ & $\begin{array}{l}\text { Area } \\
\text { Conversion } \\
\text { Factor }\end{array}$ & $\begin{array}{l}\text { Gallon } \\
\text { Conversion } \\
\text { Factor }\end{array}$ & $\begin{array}{l}\text { = Site Runoff } \\
\text { (gal) }\end{array}$ \\
\hline $\begin{array}{l}\text { River Theater } \\
\text { East }\end{array}$ & 3.70 & $6,632.00$ & 0.50 & 144.00 & 0.00 & $1,766,764.80$ \\
\hline
\end{tabular}




\begin{tabular}{|l|r|r|r|r|r|r|}
\hline $\begin{array}{l}\text { River Theater } \\
\text { West }\end{array}$ & 3.70 & $8,023.00$ & 0.40 & 144.00 & 0.00 & $1,709,861.76$ \\
\hline
\end{tabular}

\begin{tabular}{|l|l|l|l|}
\begin{tabular}{|l|l|l|} 
INFILTRATION \\
STRATEGIES AND \\
WATERING \\
REQUIREMENT \\
TOTALS
\end{tabular} & $\begin{array}{l}\text { Watering } \\
\text { Requirements }\end{array}$ & $\begin{array}{l}\text { Runoff Captured } \\
\text { by Cistern (Max } \\
2000 \text { gallons) }\end{array}$ & $\begin{array}{l}\text { Percentage of } \\
\text { Water } \\
\text { Requirements } \\
\text { Met by Cistern } \\
\text { Alone }\end{array}$ \\
\hline Marina Plaza & $6,900.68$ & N/A & \\
\hline River Theater & $2,131.82$ & 2000 & $93.82 \%$ \\
\hline TOTAL & $9,032.50$ & & \\
\hline
\end{tabular}

Table 24: Infiltration and Water Requirement Calculations. Source: LAF Research Team

*the drainage factor equation input for the River Theater is equal to the percentage of the room's surface area that drains to the cistern

Sources:

American Rivers, Center for Neighborhood Technology. 2011. The Value of Green Infrastructure: A Guide to Recognizing Its Economic, Social and Environmental Benefits. http://www.cnt.org/repository/gi-values-guide.pdf

Illinois Monthly Evaporation Data. Accessed June 26, 2019.

https://www.isws.illinois.edu/statecli/Pan-Evap/panevapx.htm.

Sasaki Associates, Inc., Ross Barney Architects, Alfred Benesch and Co., Infrastructure Engineering, Rubino and Mesia, Delta Engineering, Jacobs/Ryan Associates, Schuler Shook, Dynasty Group, and Geo Services. Chicago Riverwalk State Street to LaSalle Street Bid Drawings. PDF. Chicago: City of Chicago Dept. of Transportation Div. of Engineering, July 22, 2013.

US Department of Commerce, and Noaa. “July Precipitation Amounts for Chicago, IL." National Weather Service. January 04, 2019. Accessed June 30, 2019. https://www.weather.gov/lot/July_Precip_Rankings_Chicago.

Limitations: Though the cistern is turned off and on to irrigate, and switched to fill with potable water as necessary, this data was not available to determine a more exact metric for the actual use of the cistern. This is assuming normal precipitation for the month of July and that the cistern is not ever full of municipal water as it catches all of its water from its drainage area. It is known anecdotally from 2FM, however, that the cistern does need to be filled with municipal water at times. As such, this benefit is inconclusive. 


\section{Cost Comparison}

Seventeen 4.5-caliper trees were installed to provide more immediate shade for visitors and higher initial aesthetic value, accommodated by expanded tree pits in the River Theater. The cost to install custom tree grates was $\$ 201,380$, as compared to standard street tree grates which would have cost $\$ 43,350$. Investing an additional $\$ 158,030$ for custom tree grates allowed for the installation of trees with a more mature canopy and with a higher probability of living longer and growing larger. The lifespan of urban honey locust is estimated to be 65 years under adequate growing space and proper soil conditions, approximately 4-9 times longer than the 7-15 years of a typical urban street tree in conventional tree pits with poor soil conditions. This would save an estimated $\$ 87,600$ in replacement tree costs over time. Additionally, the appraised value of these trees in good soil conditions once mature is estimated to be nearly 18 times greater at $\$ 334,900$ than mature trees in poor soil conditions at \$18,700.

Methods: The Chicago Landscape Ordinance Manual requires that trees planted in the Greater Downtown area, of which the Chicago Riverwalk falls within, have a minimum 4 inch caliper upon installation. As such, the project team opted for 4.5 inch caliper trees to provide more canopy cover, be hardier, and have a stronger visual impact upon installation. The team designed custom tree grates that integrated into the River Theater's steps to provide large tree pits to ensure adequate soil volume, reduce soil compaction, and provide proper drainage. These were a significant investment, but the value becomes evident when compared to the cost of tree replacements every 7 to 15 years, which is typical for street trees in poor conditions according to the journal Urban Forestry and Urban Greening. The average lifespan of urban honey locust trees is 60 to 70 years according to Northern State University's The Natural Source online resource. The average of 65 years was used for the cost comparison. Additionally, the appraised value of mature trees in good and poor soil conditions were looked at to further quantify the value of the additional tree grate expense. The values used were based on James Urban's table in Up By Roots. The Willow oak was chosen for comparison because its canopy and size most closely resemble the honey locusts planted in the River Theater.

\section{Calculations:}

Tree and tree grate costs*

River Theater - 17 Gleditsia triacanthos - 4.5" caliper - \$793 each x $17=\$ 15,067$

River Theater stepped tree grate, type $A-\$ 9,340.02$ each $\times 7=\$ 65,380.14^{\star}$

River Theater stepped tree grate, type B - $\$ 13,600$ each $\times 10=\$ 136,000$ *

$\$ 65,380.14+\$ 136,000=\$ \mathbf{2 0 1}, \mathbf{3 8 0} \mathbf{1 4}$ total expense for custom tree grates

Typical 5' x 5' Chicago Tree Grate - $\$ 2,550 \times 17=\$ 43,350$ total expense for standard tree grates

$\$ 201,380.14$ - $\$ 43,350=\$ 158,030.14$ total extra expense for custom tree grates

${ }^{*}$ Costs for trees and tree grates do not include transportation/installation expenses

Urban Honey Locust Trees in Good Soil Conditions

Expected lifespan of urban honey locust $=60$ to 70 years

Average lifespan of urban honey locust $=60+70=130 / 2=65$ years 
Average lifespan of street tree in typical conditions $=7$ to 15 years

65 years $/ 7$ years $=9.3$ times replacement required

65 years $/ 15$ years $=4.3$ times replacement required

Tree Only Replacement Costs (poor soil conditions)*

Gleditsia triacanthos -4.5 " caliper price $=\$ 793$

$\$ 793 \times 4$ times requiring replacement $=\$ 3,172$

$\$ 793 \times 9$ times requiring replacement $=\$ 7,137$

Average replacement for tree only cost per tree $=\$ 3,172+\$ 7,137=\$ 10,309 / 2=\$ 5,155$

Estimated Lifetime Replacement Costs for Trees in River Theater $=\$ 5,155 \times 17$ trees $=\$ \mathbf{8 7 , 6 3 5}$

${ }^{*}$ Costs for trees do not include transportation/installation expenses

\section{Value of Mature Tree in Different Soil Conditions}

Willow oak, 10-inch dbh, in poor soil; street tree in a commercial district $\quad \$ 1,100^{*}$

Willow oak, 30-inch dbh, in good soil; street tree in a commercial district $\$ 19,700$

*slower growth rate assumed due to poor soil conditions in stressed environment

${ }^{* *}$ data based on table in James Urban's Up By Roots, 2008

$\$ 19,700 / \$ 1,100=\mathbf{1 7 . 9}$ times greater value in good soil condition

$\$ 19,700 \times 17$ trees $=\$ 334,900$ value of trees in good soil condition

$\$ 1,100 \times 17$ trees $=\$ \mathbf{1 8 , 7 0 0}$ value of trees in poor soil condition

Sources: Chicago Riverwalk Project Bid Documents.

Urban, James. Up by Roots Healthy Soils and Trees in the Built Environment. Champaign, IL: International Society of Arboriculture, 2008.

Roman, Lara A., and Frederick N. Scatena. "Street Tree Survival Rates: Meta-analysis of Previous Studies and Application to a Field Survey in Philadelphia, PA, USA." Urban Forestry \& Urban Greening 10, no. 4 (2011): 269-74. http://www.actrees.org/wpcontent/uploads/2012/08/roman-scatena-2011-street-tree-mortality.pdf.

Lara A. Roman, John J. Battles, and Joe R. McBride. "Urban Tree Mortality: a Primer on Demographic Approaches." United States Department of Agriculture, 2016.

https://www.fs.fed.us/nrs/pubs/gtr/gtr_nrs158.pdf

The Natural Source, Northern State University, "Honeylocust," accessed 26 July 2019. https://www3.northern.edu/natsource/TREESA1/Honeyl1.htm.

Limitations: Due to limited information, estimated life expectancy for honey locust trees in urban conditions may not be fully accurate. Only costs for transported trees was considered in these calculations, additional costs for soil replacement and maintenance were not considered. Estimated value of the planted honey locusts was based on a different species of tree. 


\section{Appendix A:}

Full Report - Floristic Quality Assessment for Chicago Riverwalk Phases 2 and 3

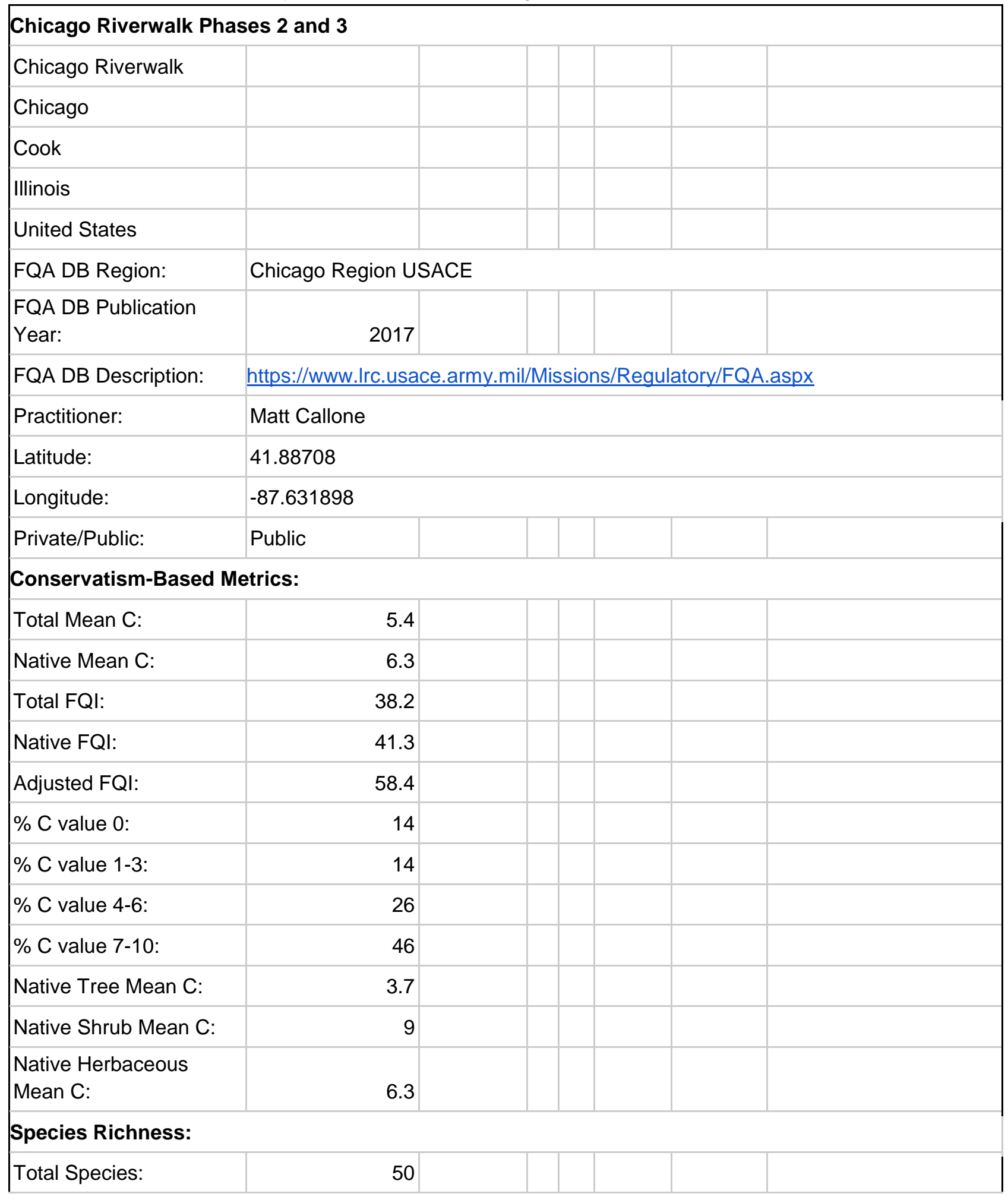




\begin{tabular}{|c|c|c|c|c|c|c|c|}
\hline Native Species: & 43 & $86 \%$ & & & & & \\
\hline Non-native Species: & 7 & $14 \%$ & & & & & \\
\hline \multicolumn{8}{|l|}{ Species Wetness: } \\
\hline Mean Wetness: & -0.4 & & & & & & \\
\hline Native Mean Wetness: & -0.5 & & & & & & \\
\hline \multicolumn{8}{|l|}{ Physiognomy Metrics: } \\
\hline Tree: & 6 & $12 \%$ & & & & & \\
\hline Shrub: & 2 & $4 \%$ & & & & & \\
\hline Vine: & 0 & $0 \%$ & & & & & \\
\hline Forb: & 32 & $64 \%$ & & & & & \\
\hline Grass: & 5 & $10 \%$ & & & & & \\
\hline Sedge: & 3 & $6 \%$ & & & & & \\
\hline Rush: & 0 & $0 \%$ & & & & & \\
\hline Fern: & 2 & $4 \%$ & & & & & \\
\hline Bryophyte: & 0 & $0 \%$ & & & & & \\
\hline \multicolumn{8}{|l|}{ Duration Metrics: } \\
\hline Annual: & 1 & $2 \%$ & & & & & \\
\hline Perennial: & 49 & $98 \%$ & & & & & \\
\hline Biennial: & 0 & $0 \%$ & & & & & \\
\hline Native Annual: & 1 & $2 \%$ & & & & & \\
\hline Native Perennial: & 42 & $84 \%$ & & & & & \\
\hline Native Biennial: & 0 & $0 \%$ & & & & & \\
\hline \multicolumn{8}{|l|}{ Species: } \\
\hline Scientific Name & Family & Native? & C & w & $\begin{array}{l}\text { Physio } \\
\text { gnomy }\end{array}$ & Duration & Common Name \\
\hline Acer rubrum & Aceraceae & native & 5 & 0 & tree & perennial & red maple \\
\hline Acorus calamus & Acoraceae & non-native & 0 & -2 & forb & perennial & single-vein sweetflag \\
\hline Alisma subcordatum & Alismataceae & native & 3 & -2 & forb & perennial & american water-plantain \\
\hline Allium canadense & Liliaceae & native & 3 & 1 & forb & perennial & meadow garlic \\
\hline Allium cernuum & Liliaceae & native & 7 & 1 & forb & perennial & nodding onion \\
\hline Ammophila breviligulata & Poaceae & native & 6 & 2 & grass & perennial & beach grass \\
\hline Asarum canadense & Aristolochiaceae & native & $\begin{array}{l}1 \\
0\end{array}$ & 1 & forb & perennial & canadian wild ginger \\
\hline
\end{tabular}




\begin{tabular}{|c|c|c|c|c|c|c|c|}
\hline Asclepias incarnata & Asclepiadaceae & native & 3 & -2 & forb & perennial & swamp milkweed \\
\hline Asclepias tuberosa & Asclepiadaceae & native & 8 & 2 & forb & perennial & butterfly-weed \\
\hline Betula nigra & Betulaceae & native & 5 & -1 & tree & perennial & river birch \\
\hline Caltha palustris & Ranunculaceae & native & 8 & -2 & forb & perennial & yellow marsh-marigold \\
\hline Camassia scilloides & Liliaceae & native & 7 & 0 & forb & perennial & atlantic camas \\
\hline Carex muskingumensis & Cyperaceae & native & 9 & -2 & sedge & perennial & muskingum sedge \\
\hline Carex stipata & Cyperaceae & native & 4 & -2 & sedge & perennial & stalk-grain sedge \\
\hline Chasmanthium latifolium & Poaceae & native & 7 & -1 & grass & perennial & indian wood-oats \\
\hline Chelone glabra & Scrophulariaceae & native & 8 & -2 & forb & perennial & white turtlehead \\
\hline Chionodoxa luciliae & Hyacinthaceae & non-native & 0 & 2 & forb & perennial & luciles glory of the snow \\
\hline Cornus mas & Cornaceae & non-native & 0 & 2 & tree & perennial & cornelian cherry \\
\hline Deschampsia cespitosa & Poaceae & native & \begin{tabular}{l|}
1 \\
0
\end{tabular} & -1 & grass & perennial & tufted hair grass \\
\hline Diervilla lonicera & Caprifoliaceae & native & $\begin{array}{l}1 \\
0\end{array}$ & 2 & shrub & perennial & dwarf honeysuckle \\
\hline Eupatorium perfoliatum & Asteraceae & native & 4 & -2 & forb & perennial & common boneset \\
\hline Geranium bicknellii & Geraniaceae & native & 4 & 2 & forb & annual & northern cranesbill \\
\hline Gleditsia triacanthos & Fabaceae & native & 1 & 1 & tree & perennial & honey-locust \\
\hline Hamamelis virginiana & Hamamelidaceae & native & 8 & 1 & shrub & perennial & american witch-hazel \\
\hline Hepatica acutiloba & Ranunculaceae & native & 8 & 2 & forb & perennial & sharp-lobe hepatica \\
\hline Hibiscus moscheutos & Malvaceae & native & 7 & -2 & forb & perennial & $\begin{array}{l}\text { crimson-eyed rose- } \\
\text { mallow }\end{array}$ \\
\hline Hosta lancifolia & Liliaceae & non-native & 0 & 2 & forb & perennial & plantain lily \\
\hline Iris virginica var. shrevei & Iridaceae & native & 5 & -2 & forb & perennial & virginia blueflag \\
\hline Jeffersonia diphylla & Berberidaceae & native & $\begin{array}{l}1 \\
0\end{array}$ & 2 & forb & perennial & twin-leaf \\
\hline Liatris aspera & Asteraceae & native & 8 & 2 & forb & perennial & rough gayfeather \\
\hline Lobelia cardinalis & Campanulaceae & native & 7 & -2 & forb & perennial & cardinal-flower \\
\hline Lobelia siphilitica & Campanulaceae & native & 4 & -2 & forb & perennial & great blue lobelia \\
\hline Mimulus ringens & Scrophulariaceae & native & 4 & -2 & forb & perennial & $\begin{array}{l}\text { allegheny monkey- } \\
\text { flower }\end{array}$ \\
\hline Nymphaea odorata & Nymphaeaceae & native & 5 & -2 & forb & perennial & american white water-lily \\
\hline Osmunda cinnamomea & Osmundaceae & native & 8 & -1 & fern & perennial & cinnamon fern \\
\hline Panicum virgatum & Poaceae & native & 3 & 0 & grass & perennial & wand panic grass \\
\hline
\end{tabular}




\begin{tabular}{|l|l|l|l|l|l|l|l|}
\hline Peltandra virginica & Araceae & native & 0 & -2 & forb & perennial & green arrow-arum \\
\hline Physostegia virginiana & Lamiaceae & native & 4 & -1 & forb & perennial & obedient-plant \\
\hline $\begin{array}{l}\text { Polystichum } \\
\text { acrostichoides }\end{array}$ & Dryopteridaceae & native & 8 & 2 & fern & perennial & christmas fern \\
\hline Pontederia cordata & Pontederiaceae & native & 9 & -2 & forb & perennial & pickerelweed \\
\hline Quercus robur & Fagaceae & non-native & 0 & 2 & tree & perennial & english oak \\
\hline Rudbeckia fulgida & Asteraceae & non-native & 0 & -2 & forb & perennial & orange coneflower \\
\hline Sagittaria latifolia & Alismataceae & native & 3 & -2 & forb & perennial & duck-potato \\
\hline Saururus cernuus & Saururaceae & native & 7 & -2 & forb & perennial & lizards-tail \\
\hline $\begin{array}{l}\text { Schizachyrium } \\
\text { scoparium }\end{array}$ & Poaceae & native & 5 & 1 & grass & perennial & little false bluestem \\
\hline Scirpus pendulus & Cyperaceae & native & 2 & -2 & sedge & perennial & rufous bulrush \\
\hline Silphium perfoliatum & Asteraceae & native & 5 & -1 & forb & perennial & cup-plant \\
\hline Solidago patula & Asteraceae & native & 9 & -2 & forb & perennial & round-leaf goldenrod \\
\hline Taxodium distichum & Taxodiaceae & non-native & 0 & -2 & tree & perennial & southern bald-cypress \\
\hline Trillium grandiflorum & Liliaceae & native & 9 & 2 & forb & perennial & large white trillium \\
\hline
\end{tabular}

\section{Appendix B}

Chicago Riverwalk User Survey Performed on July 4 and 8, 2019.

\section{Chicago Riverwalk Visitor Survey}

The Chicago Riverwalk underwent Phases 2 and 3 of its reconstruction between State Street and Lake Street, this redevelopment opening in October 2016. This survey is being taken to measure the social, environmental and economic impacts of this redevelopment. Please respond as best as possible to the following questions. This survey should take 10-15 minutes to complete. 


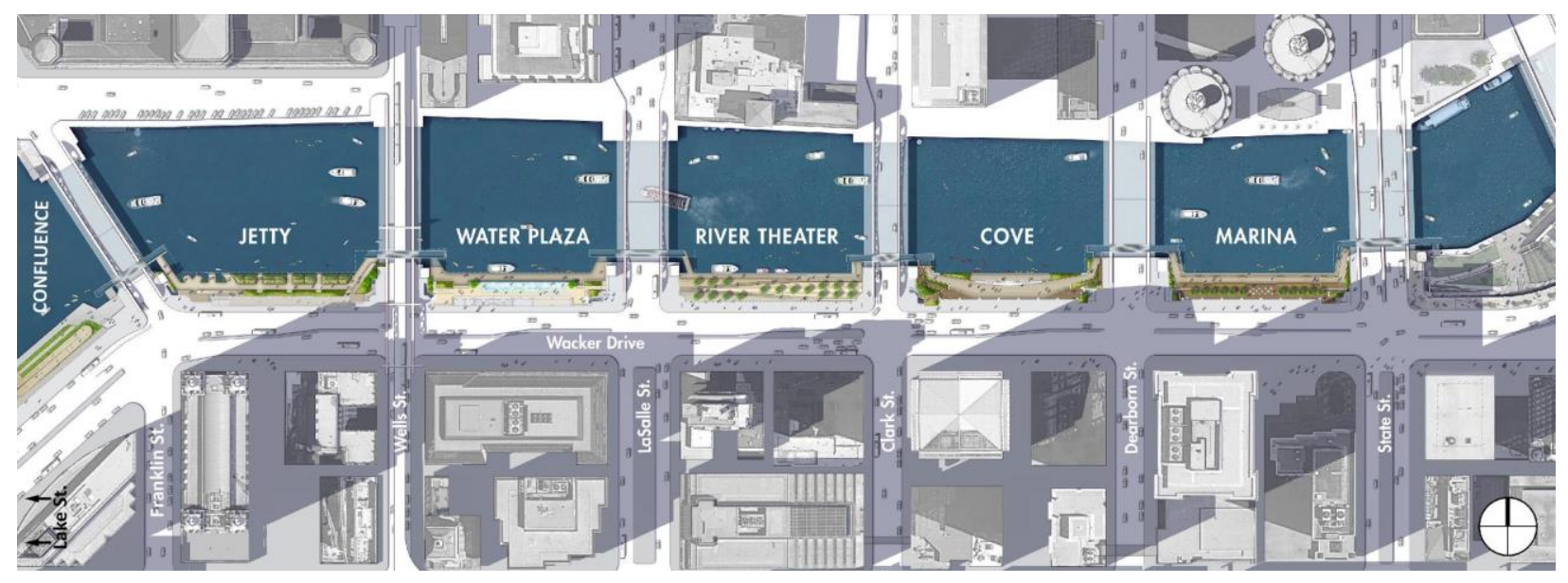

1. When visiting the Riverwalk, generally how much time do you spend here? (Please circle one)
a. This is my first visit
b. 10 minutes or less
c. 11 minutes to 30 minutes
d. 31 minutes to 60 minutes
e. 1 hour to 2 hours
f. 2 hours to 3 hours
g. More than 3 hours

2. Do you live in Chicagoland? (Please circle one)
a. Yes
b. No

3. Please rank your reasons for visiting the Riverwalk today (Please list your primary reason as 1 and 6 as lowest reason)

For physical exercise/recreation - biking, running, kayaking, fishing, walking For social reasons - Dining, meeting friends

For educational reasons - school trip, tour

For mental restoration - to "take a break" or meditative reasons For lunch/a meal Other, please describe:

4. When visiting the Riverwalk, do you patronize any of the businesses along the Riverwalk? If so, which type? (i.e. restaurants, bars, recreation) (Please select all that apply)
a. Restaurant
b. Bar
c. Recreation
d. Retail 
e. I do not spend money at any of the businesses along the Riverwalk.

5. Before or after visiting the Riverwalk, do you ever patronize businesses in the area not along the Riverwalk? If so, which type?(i.e. restaurants, bars, recreation) (Please select all that apply)
a. Restaurant
b. Bar
c. Recreation
d. Retail
e. I do not spend money at any of the businesses in the area when visiting the Riverwalk.

6. How would you rate your satisfaction with the Riverwalk in its current state compared with its previous state prior to its reconstruction in October 2016? (Please circle one)
a. More satisfied
b. Less satisfied
c. Feel the same
d. Neutral
e. I am not familiar with the site prior to its reconstruction

7. Do you find the Chicago Riverwalk to have improved in the quality of any of the following categories? (Please select all that apply)
a. Aesthetic
b. Environmental
c. Cultural
d. Accessibility
e. I am not familiar with the site prior to its reconstruction

8. Do you find that it is easier for you to get closer to the water than it was before? (Please circle one)
a. Yes
b. No
c. The same
d. I am not familiar with the site prior to its reconstruction

9. Have you taken a tour of the Chicago Riverwalk today or before? (Please circle one)
a. Yes
b. No

10. By visiting the Chicago Riverwalk today, do you have a better understanding of the river's water level and aquatic life, such as fish, within the river? (Please circle one)

c. I better understand the river's water level and aquatic life.

d. I do not better understand the river's water level and aquatic life.

e. I have the same understanding of the river's water level and aquatic life. 
11. If you have a better understanding, which elements of the Chicago Riverwalk give you a greater understanding of the river's hydrology and aquatic life? (Please select all that apply)

a. Floating wetlands

b. Posts with water levels etched onto the surface

c. Observation along the Riverwalk

d. Physical recreation in the river such as kayaking, boating

e. Educational tour

f. Other, please list:

12. Did you use the Riverwalk as part of your regular commute prior to its reconstruction in 2016? (Please circle one)
a. Yes
b. No

13. If you currently use the Riverwalk as part of your commute, what is/are your mode(s) of transportation to arrive at your final destination? (Please select all that apply)
a. Walking
b. Biking
c. Scooter/skateboard/hoverboard
d. Train to Riverwalk
e. Bus to Riverwalk
f. Water taxi
g. Other
h. The Riverwalk is not part of my regular commute

14. If you currently use the Riverwalk as part of your commute, why do you choose to use it? (Please list your primary reason as 1 and your lowest reason as 5)

_ Scenic route

_ Shorter distance or time

Environmental concern

Economic reasons Other, please specify: The Riverwalk is not part of my regular commute

15. Do you choose to use the Riverwalk as part of your commute even if it is not the shortest distance/time route? (Please circle one)
a. Yes, please explain why:
b. No
c. The Riverwalk is not part of my regular commute

16. Have you observed any conflicts with bicycles on the Riverwalk?
a. Very often
b. Somewhat often 

c. Seldom
d. Never

17. Have you observed any conflicts with Riverwalk guests drinking alcohol in public seating areas?

a. Yes, please explain

b. No

18. Do you believe allowing alcohol sold by Riverwalk vendors in the public seating areas makes the Riverwalk visit more enjoyable or less enjoyable?
a. More enjoyable
b. Less enjoyable
c. No opinion

19. Have you used the Riverwalk wayfinding maps? If so, which one(s).

a. Franklin wayfinding map

b. Wabash wayfinding map

20. What Riverwalk locations have you visited? Check all that apply. 


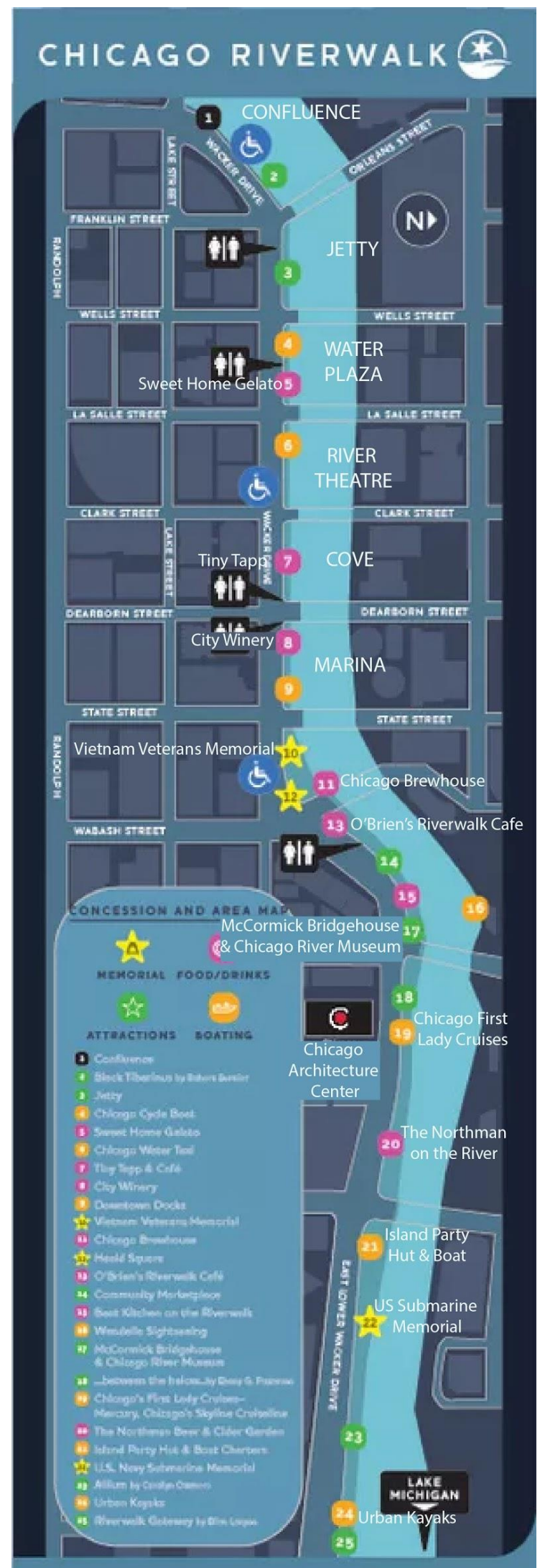

www. chicagoriverwalk.us 


Confluence (Lake to Franklin)
The Jetty (Franklin to Wells)
Water Plaza (Wells to LaSalle)
Sweet Home Gelato
River Theater (LaSalle to Clark)
Tiny Tapp and Café
City Winery
Vietnam Veteran Memorial
Chicago Brew House
O'Brien's Riverwalk Café
U

\section{Appendix C:}

Full Survey Results of Chicago Riverwalk Vendor Survey, collected in July 2019 
Chicago Riverwalk Vendor Survey

QUESTIONS

QUESTIONS

\section{0 responses}

\begin{tabular}{l|l} 
SUMMARY & INDIVIDUAL
\end{tabular}

Who has responded?

Emails REDACTED 


\section{Name of Business}

10 responses

Beat kitchen

Chicago Duffy, LLC

Tiny Tapp \& Cafe

O'Briens Riverwalk Cafe

Chicago Brewhouse

City Winery

The Northman Beer \& Cider Garden

Island Party

Chicago Riverwalk Ventures LLC

Chicago's First Lady

\section{What year did you open your business at this location?}

\section{0 responses}




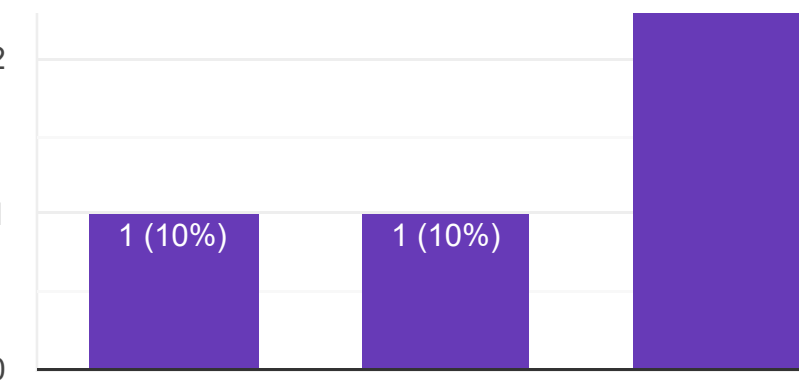

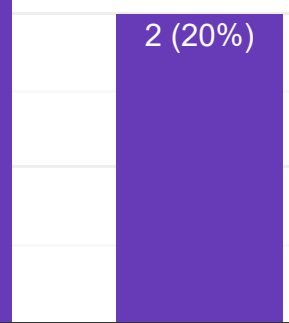

2016

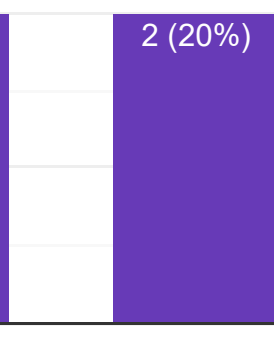

2018

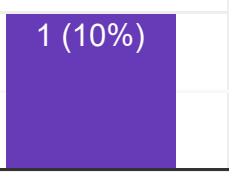

2019

\section{Why did you choose this location for your business?}

\section{0 responses}

To reach a different group of (and greater \# of) customers, since Beat Kitchen's original location is in Roscoe Village.

It is right across from our current office on the river and we knew the Riverwalk was going to be a big hit!

We were excited to be a part of the re-imagined riverwalk, and help to make the river a viable recreational amenity

The City asked us to locate the cafe at this location to establish the Riverwalk as a destination stop and help in the efforts to establish federal funding to redevelop the area

Located on Riverwalk - which has quickly become on of top tourist destinations in the City

Location

Unique Waterfront Seating Opportunity

We wanted the open area in the park feel. Not a concrete jungle.

We thought adding a non-alcohol establishment would be a big seller since the diversity of the Riverwalk patrons was more than just $21+$. There are a lot of visitors as well.

Wacker Drive reconstruction project 
3. If your business was here prior to the reconstruction of the Chicago Riverwalk Phases 2 and 3 , how has the reconstruction affected the profitability of your business?

6 responses

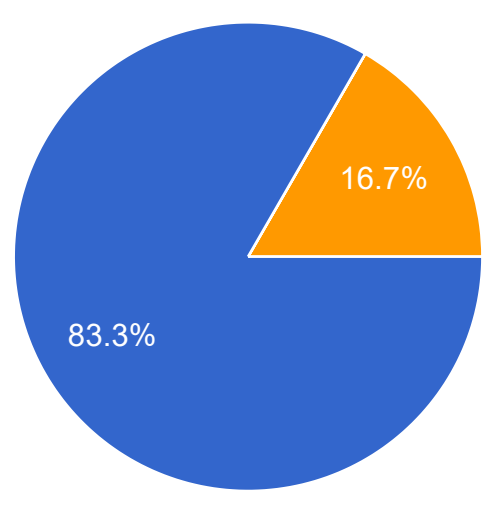

More profitable

Less profitable

Just as profitable

4. Approximately how many patrons did you serve at your Chicago Riverwalk location in 2018 ?

7 responses

13082

147000

96727 
55000

5000

40000

11339

5. Do you have another chain location elsewhere?

10 responses

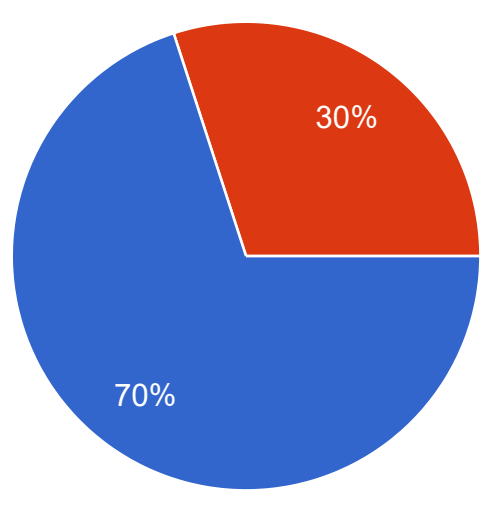

Yes

No

6. If so, how does the Chicago Riverwalk location's profitability compare to the other location?

7 responses 


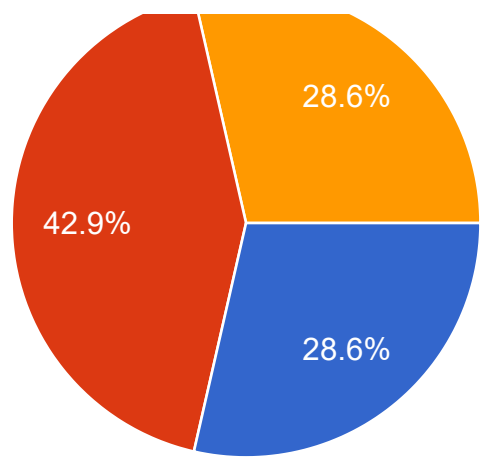

Chicago Riverwalk is less profitable

Chicago Riverwalk is just as profitable

7. How many seasonal, part-time and full-time permanent positions have you added to this location since 2016, if any? (Please specify if positions added were seasonal, part-time or full-time, i.e. "10 part-time").

9 responses

35-part time 35-full time

Approximately 140 . Ninety of which are seasonal

10 part-time - 1 full time - seasonal

Currently - 60 full time seasonal and 20 part time - same last year

1 full time and 25 part time

30

2 full time, 20 full time seasonal

35 - part time; 30 full time

Negligible changes 
8. Do you find the Chicago Riverwalk to have improved in the quality of any of the following categories? (Please select all that apply)

9 responses

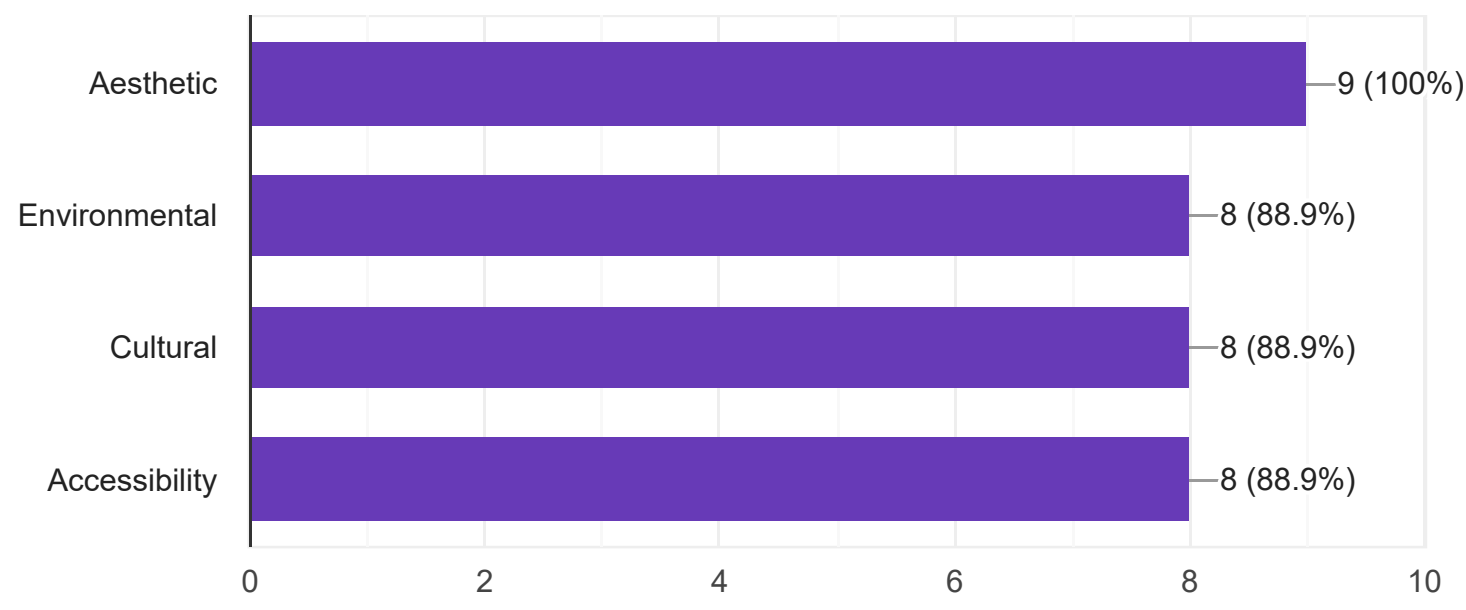

9. Have you observed any conflicts with bicycles on the Riverwalk?

10 responses

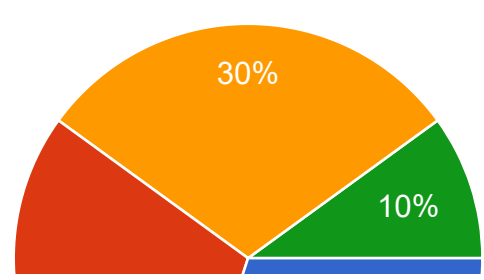


10. Have you observed any conflicts with Riverwalk guests drinking alcohol in public seating areas? If yes, please explain.

9 responses

No

No, nothing terrible

Not in our area, we a self-contained cafe

Many guests believe you can have alcohol anywhere on Riverwalk - we have to explain to them we cant sell to go and they get frustrated - they want to walk entire stretch of Riverwalk drink in hand

Only alcohol brought in from off the Riverwalk

Not really

11. Do you believe allowing alcohol sold by Riverwalk vendors in the public seating areas makes the Riverwalk visit more enjoyable or less enjoyable? 


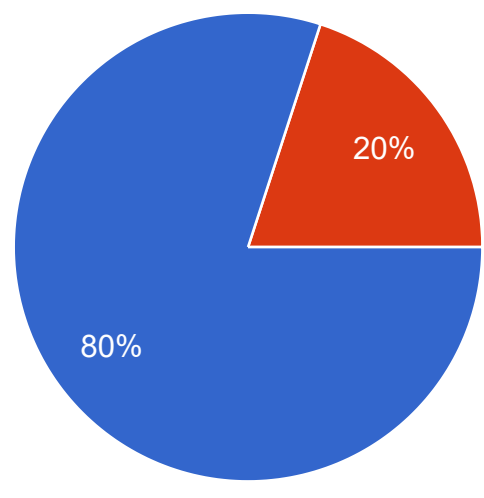

More enjoyable

Less enjoyable

No opinion

12. Have you used the Riverwalk wayfinding maps? If so, which one(s)

10 responses

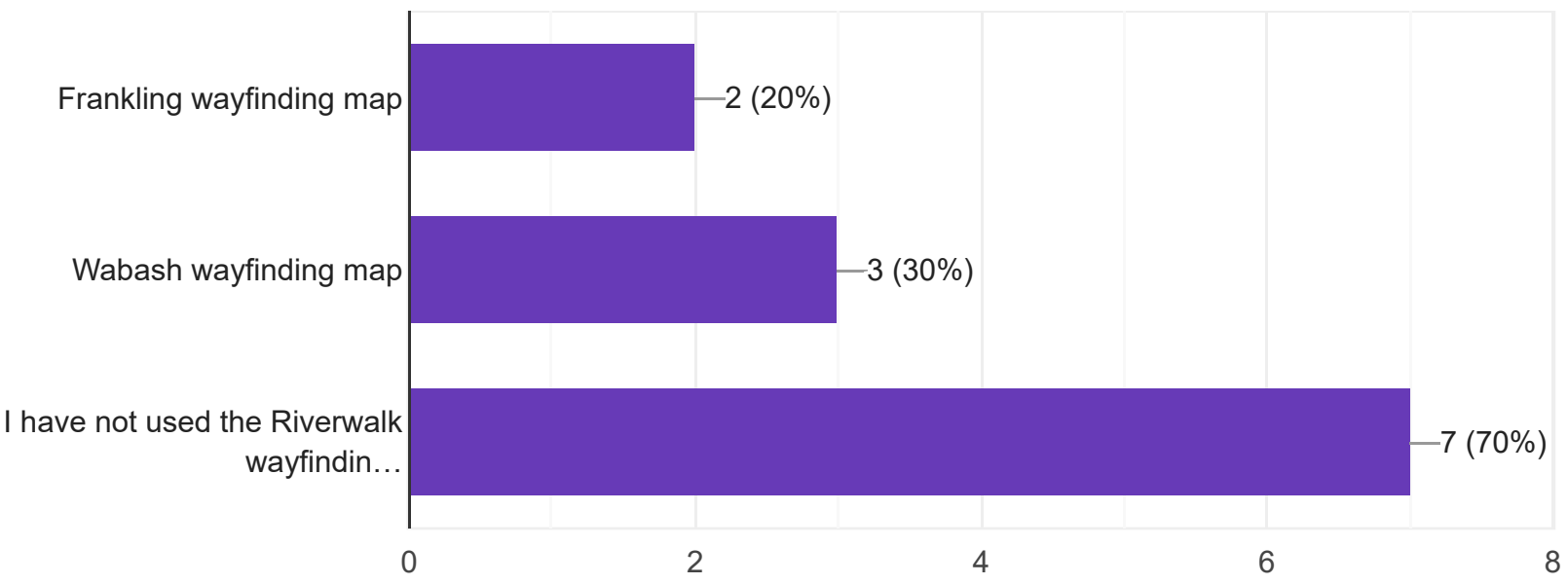




\section{What Riverwalk locations have you visited? Check all that apply. (Map below)}

10 responses

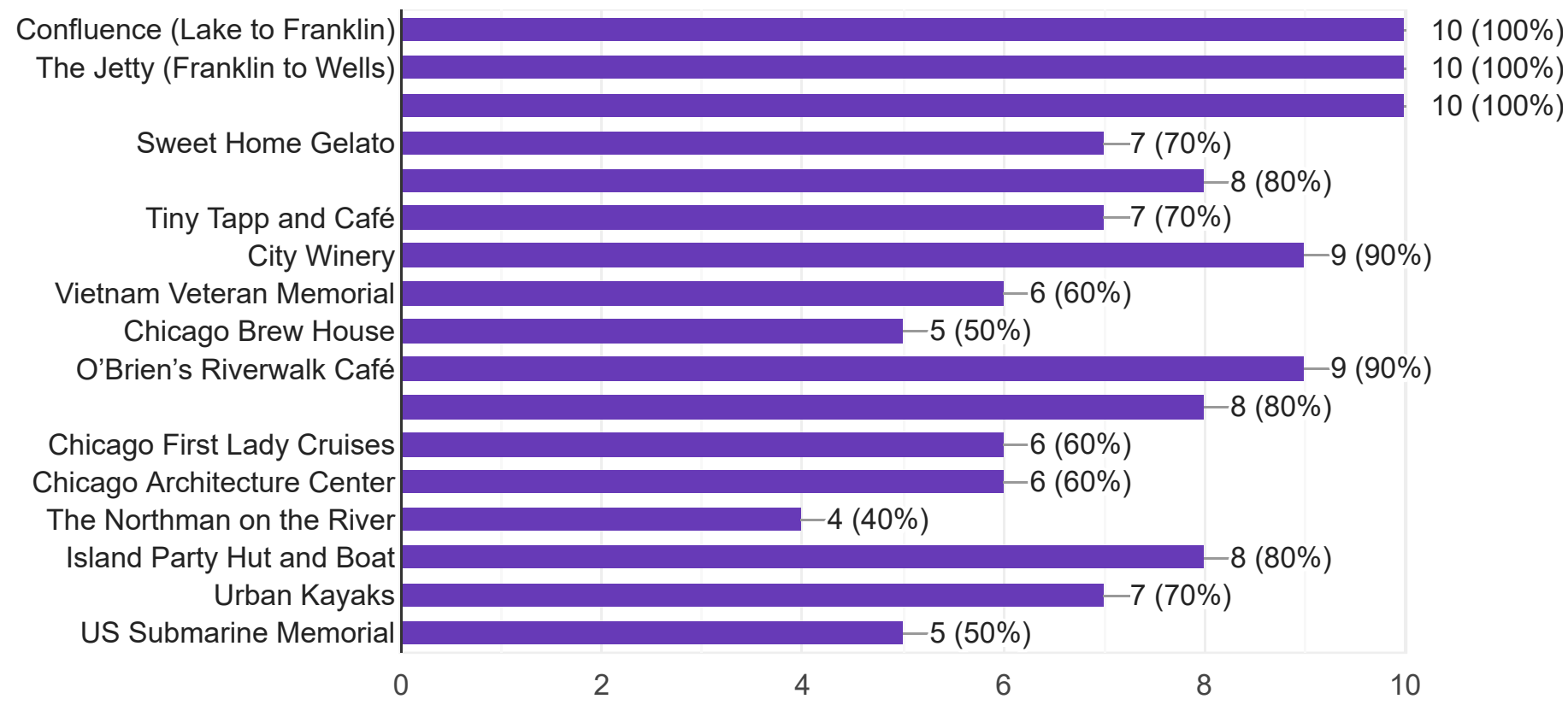

